\title{
Product Innovations, Advertising and Stock Returns
}

\author{
Shuba Srinivasan ${ }^{1}$ \\ Koen Pauwels ${ }^{2}$ \\ Jorge Silva-Risso ${ }^{3}$ \\ Dominique M. Hanssens ${ }^{4}$
}

May 7, 2008

\footnotetext{
${ }^{1}$ Associate Professor of Marketing, The A. Gary Anderson Graduate School of Management, University of California, Riverside, CA 92521-0203 (Email: shuba.srinivasan@ucr.edu).

${ }^{2}$ Associate Professor of Marketing, Tuck School of Business at Dartmouth, Hanover, NH 03755 (Email: koen.h.pauwels@dartmouth.edu).

${ }^{3}$ Associate Professor of Marketing, The A. Gary Anderson Graduate School of Management, University of California, Riverside, CA 92521-0203 (Email: jorge.silva-risso@ucr.edu).

${ }^{4}$ Bud Knapp Professor of Marketing, UCLA Anderson School of Management, Los Angeles, CA 900951481 (Email: dominique.hanssens@anderson.ucla.edu).
}

The authors are thankful to three anonymous reviewers and the JM editor, the seminar participants at the 2004 UC/USC Marketing Conference, the 2004 and 2005 Marketing Science Conferences, the 2004 MSI Conference on Collaborative Research at Yale University, the Spring 2005 MSI Board of Trustees Meeting, the 2005 Marketing Dynamics Conference, the Lally School of Management at Rensselaer Polytechnic Institute, and the University of Waikato, New Zealand for their useful suggestions. The authors thank Marnik Dekimpe, Bill Francis, Canlin Li and Harald Van Heerde for helpful comments and suggestions. Finally, the authors are grateful to the Marketing Science Institute for financial support. 


\title{
Product Innovations, Advertising and Stock Returns
}

\begin{abstract}
Under increased scrutiny from top management and shareholders, marketing managers feel the need to measure and communicate the impact of their actions on shareholder returns. In particular, how do customer value creation (through product innovation) and customer value communication (through marketing investments) affect stock returns? This paper examines conceptually and empirically how product innovations and marketing investments for such product innovations lift stock returns by improving the outlook on future cash flows. We address these questions with a large-scale econometric analysis of product innovation and associated marketing mix in the automobile industry. First, we find that adding such marketing actions to the established finance benchmark model greatly improves the explained variance in stock returns. In particular, investors react favorably to companies that launch pioneering innovations, with higher perceived quality, backed by substantial advertising support, in large and growing categories. Finally, we quantify and compare the stock return benefits of several managerial control variables.

Our results highlight the stock market benefits of pioneering innovations. Compared to minor updates, pioneering innovations obtain a seven times higher impact on stock returns, and their advertising support is nine times more effective as well. Perceived quality of the new-car introduction improves the firm's stock returns while customer liking does not have a statistically significant effect. Promotional incentives have a negative effect on stock returns, suggesting that price promotions may be interpreted as a signal of demand weakness. Managers may combine these return estimates with internal data on project costs to help decide the appropriate mix of product innovation and marketing investment.
\end{abstract}

Key words: Marketing investments, innovations, advertising, stock returns, stock-return response modeling. 


\section{Introduction}

Marketing managers are under increasing pressure to measure and communicate the value created by their marketing actions to top management and shareholders (Lehmann 2004; Marketing Science Institute 2004). These demands create a need to translate marketing resource allocations and their performance consequences into financial and firm value effects (Rust et al. 2004). In particular, how do customer value creation (through product innovation) and customer value communication (through marketing investments) affect stock returns? Several studies have identified innovation success as a key contributor to long-term firm sales, as well as to financial and stock market performance (Pauwels et al. 2004). In the same vein, Drucker (1973) cites innovation and marketing as the two factors crucial to long-term corporate health. However, new-product failure rate is high (ranging from 33\% to over 60\%) and has not improved over the last decades (Boulding, Morgan and Staelin 1997; Sivadas and Dwyer 2000). Recently, Hauser, Tellis and Griffin (2006) note that for each new-product success, the process begins with 6 to 10 concepts that are evaluated as they move from opportunity identification to launch. The high costs and risks involved with new products are the main culprit for the decline in both new-tothe-world (-44\%) and new-to-the-company (-30\%) innovations between 1990 and 2004 (Cooper 2005). The stock market's reaction to new products is not guaranteed to be warm either. For example, Boeing's stock price surged 7\% when it scrapped development plans for the $747 \mathrm{X}$ in January 1997, and it declined $1.7 \%$ when the company revived the idea two years later -- at a cost of \$4 billion -- to compete with the Airbus 380 (Wall Street Journal 1997; Dresdner Kleinwort Benson Research 2000). Similarly, there is pressure on marketing managers to demonstrate the contribution of advertising to financial performance. This is not surprising given weak evidence for the profit contribution of advertising spending (Hanssens, Parsons and Schultz 2001).

While the consumer response effects of marketing are well researched, we need a better understanding of marketing's impact on investor response, which is typically measured by stock returns. Unlike consumers, investors are motivated by cash-flow expectations, in particular the prospect of enhancing and accelerating future cash flows and of reducing associated risks (Srivastava, Shervani and Fahey 1998). Moreover, many marketing actions are costly, and investors consider both their (expected) benefits and downsides. Furthermore, the stock-return

impact of marketing actions needs to be assessed in the presence of other important drivers, as 
identified in the accounting and finance literature (Fama and French 1992; Kothari 2001). Thus, our central research question is: To what extent do marketing actions improve stock returns, over and above the typical finance and accounting benchmark measures?

Our empirical research focuses on one industry, automobiles, in order to enhance its internal validity. Moreover, we believe that findings in this industry will be generalizable to other settings, as a meta-analysis (Capon, Farley and Hoenig 1996, p. 214) indicates few industry-specific effects of innovation performance, and while high returns need not be sustainable in any particular market, the process of generating high returns can be sustainable.

The automobile industry is of substantial economic importance, representing over $3 \%$ of the U.S. Gross Domestic Product (J. D. Power and Associates 2002). In addition, the industry relies heavily on new products, promotional incentives and advertising. The main thrust of competition is in product development, with each company competing in multiple market segments "with a plethora of niche models designed to attract a particular group of consumers, and to renew them rapidly enough to keep interest fresh" (The Economist 2004, p.14). However, the costs of such design changes can be substantial, and their success is far from certain. Therefore, large automobile firms face substantial innovation investment decisions across distinct product categories (called 'segments' in industry parlance) that differ in category attractiveness and competitive conditions. Further, automobile manufacturers invest billions of dollars every year in various forms of advertising to influence customers and prospects to buy their products and services. General Motors alone spent over $\$ 2.8$ billion in 2004 to advertise its lines of automobiles (TNS Media Intelligence 2005). However, concerns persist about the financial impact and wisdom of such substantial communications spending.

The remainder of this paper is organized as follows: First, we develop the research framework and specify a comprehensive stock-return response model to quantify these relationships. Next, we discuss the marketing and financial data sources and estimate the models. Finally, we formulate conclusions, cross-validate the empirical results, and discuss their implications for marketing strategies.

\section{Research Framework}

We start with the established financial benchmark, i.e. the four-factor model by Fama and French (1992; 1993), because this model produces a better estimate of expected stock returns than does 
the Capital Asset Pricing Model (CAPM). The four-factor model posits that the expected rate of return of a stock portfolio is a function of risk factors that reflect the market, size, book-tomarket and momentum factors. Additionally, previous literature in accounting and finance has demonstrated that stock returns react to changes in firm financial measures, including firm results such as firm revenues and firm earnings. (e.g., Kothari 2001). Controlling for these factors, we develop a conceptual framework to capture the effects of marketing activity on stock returns. We argue that such impact on firm valuation may occur through one or more of four routes: (1) enhancing cash flows, (2) accelerating cash flows, (3) reducing vulnerability in cash flows and (4) increasing the residual value of the firm.

First, marketing investments, which can involve substantial costs in the short run, can increase shareholder value by enhancing the level of cash flows (i.e., more cash), notably by increasing revenues and lowering costs. As an example, automobile innovations that are responsive to unmet customer needs in specific segments, including the Ford Mustang for young drivers and the Chrysler Minivan for families with children, have resulted in substantial revenue increases for these companies. Second, marketing investments can enhance shareholder value by accelerating the receipt of cash flows (i.e., faster cash). This is especially important in high-fixed cost industries that depend on fast turnovers to finance their operations. As an example, aggressive advertising helps develop instant awareness of new products that may accelerate the diffusion process. Third, marketing investments can increase shareholder value by lowering the vulnerability and volatility of these cash flows (i.e., safer cash), which results in a lower cost of capital or discount rate (Srivastava, Shervani and Fahey 1998). ${ }^{1}$ Thus, all else equal, cash flows that are predictable and stable have a higher net present value and thus create more shareholder wealth. For example, advertising may help smooth out the variability in highly seasonal demand patterns or, alternatively, to accentuate them (e.g., Fischer, Shin and Hanssens 2007). Finally, marketing investments may increase the residual value of the firm. Building brands and keeping them relevant and distinctive, e.g. by pioneering innovations, will increase the equity of the brands owned by the firm and thus its residual value.

The outlook for investors on enhancing, accelerating and stabilizing the firm's cash flows, and increasing its residual value, can be influenced by marketing actions. We formulate the hypotheses in this section in terms of which brand-level marketing actions influence the stock returns, modeled through the main effect as well as the interaction effect with new-product 
introductions. Figure 1 and Table 1 present a summary of these drivers and their hypothesized effects.

--- Insert Figure 1 and Table 1 about here ---

\section{Marketing Actions and Stock Returns}

Innovativeness. The innovativeness, or relative advantage of new products, is a consistently important determinant of accelerated consumer adoption rate (Holak and Lehmann 1990) and new-product success (Montoya-Weiss and Calantone 1994). Based on venture portfolio theory (Booz, Allen and Hamilton 1982), the extent of innovation in new products can be classified based on two dimensions: new-to-the-company and new-to-the-market. ${ }^{2}$ The first dimension measures the extent to which the new product introduction is innovative compared to the firm's existing products. The second dimension measures the extent to which the firm's new product is a new introduction to the market. An example of a new-to-the-company innovation within the automobile industry context is the Porsche Cayenne, which was the first SUV developed by the company (and thus scores highly on the first dimension, offering Porsche-loyals the opportunity to drive an SUV), but which entered a market already full of SUVs, including the sporty carbased BMW X5 (and thus scores low on the second dimension). As for the second dimension, an example of a new-to-the-market innovation is the Toyota Prius hybrid. We discuss the impact of these innovation dimensions, in turn.

New-to-the-Company: Innovation Level. Renewing one's products is widely regarded as necessary for long-term survival and as an engine of growth, thus enhancing cash flows and future profitability (Chaney, Devinney and Winer 1991; Sorescu, Shankar and Kushwaha 2007). Recent evidence on new-product introductions, in the context of the PC market, suggests that enhancement in cash flows occurs due to reduced selling and general administrative expenses (Bayus, Erickson and Jacobson 2003). On average, the higher the new product's improvement over previous versions, the higher its long-term financial performance and firm-value impact (Pauwels et al. 2004). In line with J.D. Power and Associates' expert rating scale, we consider the range from mere trimming and styling changes (levels 1 and 2) to 'design' and 'new benefit' innovations (levels 3 and 4) to brand entry in a new category (level 5) in the empirical analysis (ibid). 
Developing new products faster and moving them into production can accelerate cash flows from product innovation (Srivastava, Shervani and Fahey 1999). In contrast, many products have failed to realize their potential because of insufficient attention to speeding up the market acceptance cycle for these products (Robertson 1993). Large companies, especially, have been criticized for delaying the renewal and upgrade of their product offerings in the face of changing consumer preferences (Ghemawat 1991). Furthermore, the success of innovations depends on the timely adoption of the innovation by consumers, with both consumer and market factors being important drivers of the trial probability (e.g., Gielens and Steenkamp 2003).

Companies can reduce the vulnerability of their cash flows by completing their product portfolio with new-to-the-company products that allow them to address new consumer segments. For example, Toyota reduces cash-flow volatility by offering a full line of products and managing the migration of customers from its economy models to its luxury cars, from Yaris to Corolla, for example, or from to Camry to Lexus ES. Furthermore, synergies between and within product lines, including sharing components and design elements across such different products, can reduce production costs and inventory risk (Fisher, Ramdas and Ulrich 1999). Additionally, a higher innovation level may also increase the residual value of the company. In the face of shifting demand and fickle consumer preferences for the newest products, brands with more improvements from one model to the next are more likely to remain fresh and thus relevant to today's and tomorrow's consumers.

Finally, recent empirical evidence suggests a non-linear effect of the innovation level on new product success. On the demand side, Gielens and Steenkamp (2003) find U-shaped effect of product novelty on product trial probability. Within a range of (non-radical) innovations like those in their and our study, consumers prefer either low complexity (minor update) or high relative advantage (new market entry). Moderate innovations typically do not offer (much) more advantage over minor innovations (Cooper and Kleinschmidt 1991) and thus appear stuck in the middle. On the supply side (Sherman and Hoffer 1971), 'design' and 'new benefit' innovations (levels 3 and 4 our scale) are much costlier than mere trimming and styling changes (innovation levels 1 and 2). For example, Cadillac's Escalade SUV innovation cost General Motors around \$ 4 billion (White 2001). Combined with the U-shaped demand impact, financial performance thus shows a U-shaped impact of innovation level (Pauwels et al. 2004). Between minor updates and new market entries, the latter are better news for the firm's future value, as "products high on 
newness provide an especially strong platform for growth” (Gielens and Steenkamp 2007, p. 104). While minor innovations are necessary to maintain the stable stream of cash flows from “bread-and-butter” products (e.g., Toyota’s frequent minor updates to Camry), major product updates are better able than minor product updates to enhance cash flows (Kleinschmidt and Cooper 1991) and thus stock returns. In sum, we expect the stock-return benefits to have a Ushaped relationship with each innovation level in this scale, with a preference for new market entries over minor updates.

$\mathrm{H}_{1 \mathrm{a}}$ : New-to-the-company innovations increase stock market returns.

$\mathrm{H}_{1 \mathrm{~b}}$ : Stock returns are U-shaped in the level of new-to-the-company innovation.

Pioneering Innovations. While new-product introductions benefit stock returns on average, newto-the-market products have a higher impact (Chaney, Devinney and Winer 1991). Indeed, the new-product literature has consistently related innovation success to the product's ability to provide benefits and features not offered by alternative products (Holak and Lehmann 1990; Henard and Szymanski 2001). Pioneering innovations have better potential to unlock previously unmet customer needs and thus ultimately surpass me-too innovations in terms of enhancing cash flows (Kleinschmidt and Cooper 1991; Moorman and Miner 1997).

It is not clear a priori whether or not pioneering innovations will accelerate cash flows compared to other innovations. On the one hand, relative advantage is a consistently important determinant of accelerated adoption rate (Holak and Lehmann 1990). On the other hand, consumers may also consider pioneering innovations riskier, which delays adoption (Gatignon and Robertson 1985).

Finally, pioneering innovations also stand out as reducing cash flow vulnerability and raising residual value. Indeed, while the short-term risk may appear higher, pioneering products also have option value; i.e., they "offer the possibility for greater long-term financial gain given the possibility of revolutionizing the category” (Moorman and Miner 1997). Indeed, firms can reduce the vulnerability of their cash flows by staying ahead of competition in product innovation and introducing hard-to-copy new products. Moreover, investors may view such pioneering innovations both as platforms for future product introductions and as signals that the firm is successful in the innovation process itself. Therefore, their view of the residual value of the firm is likely enhanced. Finally, pioneering innovations offer new strategic choices for the 
firm by providing the opportunity to leverage these innovations to future products. For example, Dupont has leveraged their invention of nylon and Teflon in a series of successful new-product introductions in a variety of categories. At the same time, radical pioneering innovations are likely to increase the volatility of cash flows in the short run but can eventually lead to stable cash flows. A notable example of a radical pioneering innovation is the Toyota Prius hybrid, which is tracking to commercial success as a result of radical but visionary strategy. Overall, we postulate:

$\mathrm{H}_{2}$ : Pioneering (new-to-the-world) innovations have a higher stock-return impact than nonpioneering innovations.

Advertising Support. Research over the past decade has shown that marketing activity such as advertising can lead to more differentiated products characterized by lower own-price elasticity (Boulding, Lee and Staelin 1994). This in turn, enables the company to charge higher prices, attain greater market share and sales (Boulding, Eunkyu and Staelin 1994), command consumer loyalty (Kamakura and Russell 1994), and hence, ward off competitive initiatives. Empirical evidence from the automobile market suggests that advertising expenditures generate greater cash flows for pioneers than for later entrants (Bowman and Gatignon 1996). Therefore, advertising support for innovations, especially pioneering innovations, can enhance cash flows for the company.

Second, advertising builds awareness, which is an essential component of new-product success. Bly (1993, p. 125), for example, notes that the "new-product innovator will spend more than twice as much on advertising and promotion as a business with fewer new products." Recent evidence suggests that firms which invest more in marketing resources can better sustain the innovation and, hence, accelerate the adoption rate of their new products (Chandy and Tellis 2000). These benefits can lead to cash flow acceleration.

Third, investments in the brand through advertising can reduce consumers' perceived risk, particularly for radical innovations (Dowling and Staelin 1994). As such, differentiation of a brand through advertising may lead to monopolistic power which can be leveraged to extract superior product-market performance, leading to more stable (i.e., less vulnerable to competition) earnings in the future (Srivastava, Shervani and Fahey 1998). On the other hand, 
advertising spending could exacerbate or smooth seasonal demand patterns leading to either an increase or a decrease in volatility, respectively.

Likewise, the increased brand differentiation through advertising should increase the residual value of the firm. Moreover, investors may perceive enhanced residual value through advertising exposure, above and beyond its impact on firm financial performance (Joshi and Hanssens 2007). Therefore, we hypothesize:

$\mathrm{H}_{3 \mathrm{a}}$ : Advertising support for new-to-the-company innovations increases the stock market returns of these innovations.

$\mathrm{H}_{3 \mathrm{~b}}$ : Advertising support for pioneering innovations increases the stock market returns of these innovations.

While we expect advertising to work for both new-to-the-company and new-to-the world innovations, the latter should benefit most. Indeed, advertising works best when the firm has something new to offer the consumer (Lodish et al. 1995). When the product innovation is so pioneering that it (temporarily) dominates the competition, firms may even reap permanent benefits from their advertising campaigns (Hanssens and Ouyang 2002). Therefore, we expect that:

$\mathrm{H}_{3 \mathrm{c}}$ : Advertising support benefits the stock market returns more for pioneering innovations than for new-to-the-company innovations.

Promotional Support. The power of sales promotions to enhance future cash flows has been investigated extensively in empirical research. On the one hand, sales promotions are effective demand boosters as they often have substantial immediate effects on sales volume and profits (Dekimpe and Hanssens 1999). In terms of the conceptual framework, the main power of price promotions is to accelerate cash flows, which is why they are often used by managers to reach sales quotas on time (e.g., Lee, Padmanabhan and Whang 1997). On the other hand, promotions also signal a weakness in the customer value of the product relative to competition, particularly in the context of new-product introductions (Pauwels et al. 2004).

To the extent that sales promotions have positive short-term effects on top-line and bottom-line performance (Nijs et al. 2001; Srinivasan et al. 2004), the use of sales promotions would accelerate cash flows. However, since promotion effects on sales are typically short-lived, any positive cash flow response will dissipate quickly. 
Additionally, for durable products (and particularly for automobiles), manufacturers need to build and commit capacity before the product is launched. Promotions and price discounts could signal that the new product is performing below expectation in terms of sales, which, in turn, would lead to either low capacity utilization or a chronic dependence on price discounts. Hence, price discounts could be interpreted as signaling profit compression in the future. Especially important for automobiles, price promotions on new vehicles may reduce the secondhand and trade-in market for used vehicles, which in turn, affect the residual value of the firm's portfolio of leased cars. Therefore, we postulate:

$\mathrm{H}_{4}$ : Promotional support for new-to-the-company innovations decreases the stock market returns of these innovations.

Customer Perceptions of Brand Defects and Brand's Perceived Quality. In general, marketing theory predicts greater success for firms that serve the needs of their customers better, especially by providing products that are superior to the competition in the customers' eyes (Griffin and Hauser 1993). Within the automobile industry, management can significantly improve their company's fortunes by introducing new products with superior features and minimal deficiencies (e.g., GM's recent push for more pleasing new cars with fewer defects). Customer-focused measures of these improvements include customer liking, quality and satisfaction. In markets for pioneering innovations, prior evidence suggests that the initial growth in customer base and revenue is largely due to perceived quality improvements by incumbents as well as new entrants (Agarwal and Bayus 2002). In other words, innovations that create and deliver added consumer value contribute significantly to the success of brands (Kashani, Miller and Clayton 2000).

Apparently, investors view the quality signal as providing useful information about the future-term prospects of the firm: Changes in perceived quality are associated with changes in stock returns (Aaker and Jacobson 1994; Tellis and Johnson 2007). Favorable perceptions of product quality and value by customers lead to differentiation and higher brand loyalty, which, in turn, lead to higher buyer switching costs that can be exploited to enhance current profitability and cash flows or to increase the residual value of the firm.

A priori, it is unclear whether customer liking and perceived quality will also accelerate cash flows. Regarding cash flow stability, brands with favorable perceptions of product quality likely enjoy a greater degree of “monopolistic competition” power. In other words, high 
customer quality perceptions represent competitive barriers that reduce price elasticity and generate more stable (i.e., less vulnerable to competition) earnings in the future. In sum, we postulate:

$\mathrm{H}_{5}$ : Customer liking of new-product introductions increases stock returns.

$\mathrm{H}_{6}$ : $\quad$ Perceived quality of new-product introductions increases stock returns.

\section{Category Characteristics}

We consider four category characteristics as control variables - category size, category growth rate, firm's share of the category and category concentration - based on previous literature (e.g., Capon, Farley and Hoenig 1996). While previous marketing literature was helpful in formulating hypotheses on the impact of marketing actions on stock returns (H1-H6), here our empirical analysis is exploratory given the need for studies that examine the impact of category characteristics on stock returns. As such, we formulate expectations on the direction of the effects rather than formal hypotheses at this juncture.

Category Size. ${ }^{3}$ The strength of category demand is an important factor in brand success, and firms neglect market size assessment at their own peril (Cooper and Kleinschmidt 1993; Henard and Szymanski 2001). On the one hand, large categories enable firms to spread their fixed R\&D and launch costs over a greater number of potential customers. On the other hand, large categories are also attractive to competitors and, thus, will draw more competitive innovation and attention. Going after larger categories may also reduce the vulnerability of a firm's cash flows. If the new-product introduction misses its intended mark, other consumers in the large category may have an interest. For example, when Cadillac launched a redesigned Escalade SUV in 2002, it became highly successful with an unintended market segment -- professional athletes, rappers and celebrities. Cadillac, in turn, has started to pursue these trendsetters by giving them previews of the next-generation Escalade, offering them limited-edition versions, etc. (Eldridge 2004). Moreover, large categories may provide a better cushion against damage by competitive marketing actions or exogenous changes (Aaker and Jacobson 1990).

Category Growth Rate. Firms that target high-growth categories achieve higher sales and financial performance, leading to enhanced cash flows (Capon, Farley and Hoenig 1996). Moreover, competitive reactions to new-product introductions are likely to be less aggressive when the incumbent sales continue to grow at a satisfactory rate, which would be the case when 
the product innovation increases primary demand (Frey 1988). Likewise, advertising reactions to new-product introductions are less likely in growing versus static categories (Cubbin and Domberger 1988). This lower competitive intensity leads, in turn, to enhanced cash flows. Moreover, investments are preferentially directed toward high-growth categories and away from established businesses in slower growth categories (Wensley 1981) because the expected payoff is better in high-growth categories. Similarly, when the category demand is growing, it is easier for all competitors to acquire customers rapidly, leading to acceleration in cash flows (Cooper 1999; Scherer 1980).

Finally, commitment of marketing resources in emerging growth categories reduces risk in the future. Indeed, investors are likely to reward share gains in growing categories because the returns are expected to grow as the category grows.

Firm's Share of Category. The firm's current market share in a category may impact its longterm performance in several ways. A firm's high market share typically results from a strong relative advantage in the served segment (Phillips, Chang and Buzzell 1983), which in turn enhances cash flows. At the same time, dominant firms have more to lose from cannibalization (Chandy and Tellis 2000), which could jeopardize the price premiums on their established products. This has an opposite impact on cash flows. In addition, it is unclear a priori to what extent the firm's share of the category affects the acceleration of cash flows from new-product introductions. Finally, the volatility of cash flows is reduced when the firm has a dominant market share, and is therefore more likely to retain a large proportion of customers on an ongoing basis (Srivastava, Shervani and Fahey 1998). However, firms with a large share of a category may become complacent in that category as their managerial priorities shift to other, higher-growth opportunities (Kashani 2003), leading to increased vulnerability in cash flows. Given these opposing forces, we explore the effect of firm category share.

Category Concentration. A brand's success critically depends on competitive category conditions, including category concentration (Cooper and Kleinschmidt 1993; Capon, Farley and Hoenig 1996). Economic theory suggests that in concentrated categories, profit margins are higher. Moreover, companies in concentrated categories are less motivated to engage in price wars, as they dissipate the attractive margins. Thus, increases in category concentration are more likely to increase cash flows and, hence, stock returns. Finally, faced with only a few competitors, a firm is less likely to be surprised by disruptive innovations that impact the 
stability of its income streams. Therefore, category concentration will likely reduce the vulnerability of cash flows.

\section{Research Methodology}

We use stock-return response modeling to assess the degree to which marketing actions and category conditions improve the outlook on a firm's cash flows and thereby lift its stock price. In essence, stock-return response modeling establishes whether the information contained in a measure is associated with changes in expectations of future cash flows and, hence, stock price and returns (see Mizik and Jacobson 2004 for review). We present a “unified” estimation of firm stock returns by specifying a model that allows us to directly assess the proposed hypotheses.

\section{Stock-Return Response Modeling}

It is well known that the economic return to a marketing activity such as a new-product introduction is obtained over the long term (e.g., Pauwels et al. 2004). Therefore, we may consider a firm's marketing activity as an intangible asset that influences future cash flows. As such, "the value of a marketing strategy to the firm can be depicted as the net present value of future cash flows generated through the use of this marketing strategy” (Mizik and Jacobson 2003, p. 67).

The stock market valuation of a firm depicts the market expectations of these discounted future cash flows. The efficient market hypothesis (EMH) implies that stock prices follow random walks: The current price reflects all known information about the firm's future earnings prospects (Fama and French 1992). For instance, investors may expect the firm to maintain its usual level of advertising and price promotions. Developments that positively affect future cash flows result in increases in stock price while those negatively affecting cash flows result in decreases. While changes to typical marketing time series such as consumer sales are mostly temporary (Ehrenberg 1988; Dekimpe and Hanssens 2000), changes to stock prices are predominantly permanent (Fama and French 1992; Malkiel 1973). By taking the first differences of the logarithm of stock prices, a stationary time series of stock returns is obtained as a dependent variable. In the context of this paper, regressing stock returns against changes in the marketing mix provides insights into the stock market's expectations of the associated long-term changes in cash flows. 


\section{Assessing the Impact of Marketing Actions on Stock Returns}

The framework for assessing the information content of a measure enjoys a long tradition in finance (e.g., Ball and Brown 1968) and in marketing (see, for example, Jacobson and Aaker 1993; Madden, Fehle and Fournier 2006). The latter research stream has sought to assess the stock market reactions to non-financial information including firms' customer-based brand equity (Aaker and Jacobson 2001; Barth et al. 1998), brand extension announcements (Lane and Jacobson 1995), online channel addition (Geyskens, Gielens and Dekimpe 2002), and a shift in strategic emphasis from value creation to value appropriation (Mizik and Jacobson 2003). In the tradition of stock-return response modeling, these studies test for incremental information content, that is the degree to which a series explains stock price movements above and beyond the impact of current accounting measures such as revenue and earnings.

We start from a well-established benchmark in the finance literature, i.e. the four-factor explanatory model, which estimates the expected returns (Eret ${ }_{i t}$ ) as a function of risk factors that reflect the general stock market, the specific firm's size, the relative importance of intangibles (book-to-market ratio) and stock-return momentum (Fama and French 1992; 1993). Riskier stocks are characterized by higher returns, so smaller firms are expected to outperform larger firms, stocks with higher book-to-market ratios are expected to outperform stocks with lower book-to-market ratios, and stocks with higher momentum (i.e., high past return) are expected to outperform stocks with lower momentum. The typical financial benchmark model for stock returns is estimated as follows:

$$
R_{i t}-R_{r f, t}=\alpha_{i}+\beta_{i}\left(R_{m t}-R_{r f, t}\right)+s_{i} S M B_{t}+h_{i} H M L_{t}+u_{i} U M D_{t}+\varepsilon_{i t}
$$

where $R_{i t}$ is the stock return for firm $i$ at time $t, R_{r f, t}$ is the risk-free rate of return in period $t, R_{m t}$ is the average market rate of return in period $t, S M B_{t}$ is the return on a value-weighted portfolio of small stocks minus the return of big stocks, $H M L_{t}$ is the return on a value-weighted portfolio of high book-to-market stocks minus the return on a value-weighted portfolio of low book-tomarket stocks, and $U M D_{t}$ is the average return on the two high prior return portfolios minus the average return on the two low prior return portfolios (i.e., momentum). Moreover, $\varepsilon_{i t}$ is the error term; $\alpha_{i}$ is the model intercept; and $\beta_{i}, s_{i}, h_{i}$ and $u_{i}$ are parameter estimates of the four factors used in the model. The SMB and HML factors are constructed using portfolios formed on size and book-to-market while the UMD factor is constructed using portfolios formed on prior 2 to 12 month returns. More details on the four factors and related data are available on Kenneth 
French's web site. ${ }^{4}$ If the stock's performance is "normal" given its market risk, size, book-tomarket and momentum characteristics, the four-factor model captures the variation in $R_{i t}$, and $\alpha_{i}$ is zero.

Next, we augment the financial benchmark model (Equation 1) with marketing variables in order to test hypotheses on their impact on future cash flows. As argued above, we express the marketing variables in unanticipated changes, i.e., deviations from past behaviors that are already incorporated in investor expectations. The model is defined at the brand level and the category level, as follows:

$$
\begin{aligned}
& R_{i t}-R_{f t}=\operatorname{Eret}_{i t}+\beta_{1} U \Delta I N C_{i t}+\beta_{2} U \Delta R E V_{i t}+\sum_{l=1}^{5} \beta_{3} U \Delta I N N D_{i j k t, l}+\beta_{4} U \Delta C I N N_{i j k t} \\
& +\beta_{5} \text { PION }_{i j k t}+\beta_{6} \text { CPION }_{i j k t}+\sum_{o w n=1}^{4} \beta_{7, \text { own }} U \Delta O M K T_{i j k t, o w n}+\sum_{c \text { rosss } 1}^{4} \beta_{8, \text { cross }} U \Delta C M K T_{i j k t, \text { cross }} \\
& +\sum_{n=1}^{4} \beta_{9, n} U \Delta C A T_{k t, n}+\gamma_{1} U \Delta I N C_{i t} \times U \Delta I N N_{i j k t}+\gamma_{2} U \Delta R E V_{i t} \times U \Delta I N N_{i j k t} \\
& +\sum_{o w n=1}^{4} \gamma_{3, o w n} *\left(U \Delta O M K T_{i j k, o w n} \times U \Delta I N N_{i j k t}\right)+\sum_{o w n=1}^{4} \gamma_{4, o w n} *\left(U \Delta O M K T_{i j k, o w n} \times P I O N_{i j k t}\right) \\
& +\sum_{c \text { ross }=1}^{4} \gamma_{5, \text { cross }} *\left(U \Delta C M K T_{i j k t, \text { crosss }} \times U \Delta I N N_{i j k t}\right)+\sum_{n=1}^{4} \gamma_{6, n} *\left(U \Delta C A T_{k t, n} \times U \Delta I N N_{i j k t}\right)+\varepsilon
\end{aligned}
$$

where $R_{i t}$ is the stock return for firm $i$ at time $t$, Eret $_{i t}$ is the expected return from the FF benchmark model in equation (1) and the subscripts $j$ and $k$ denote the brand and category and $l$ denotes the innovation level. The inclusion of brand and category subscripts is relevant for two reasons: first, since the stock-return impact is likely to be different across brands and categories due to cross-sectional heterogeneity, it is important to account for such heterogeneity from an econometric perspective. Second, managers would like to pinpoint which brands (e.g., those with more versus less advertising support, innovation level, quality, etc.) and/or targeted categories contribute more or less to the firm's stock return. The subscripts own and cross denote own and competitive marketing variables (advertising, promotional incentives, liking and quality).. The subscript $n$ denotes the category variables (size, growth rate, concentration and the market share of the firm in the category). The unexpected components of stock returns are of two kinds: results and actions or signals. Results include unanticipated accounting earnings (UAINC) and revenues (UAREV). Specific marketing actions or signals are the unanticipated changes to brand innovation (UAINND), pioneering innovations (PION) and the 
unanticipated changes to advertising, promotions, customer liking and perceived product quality

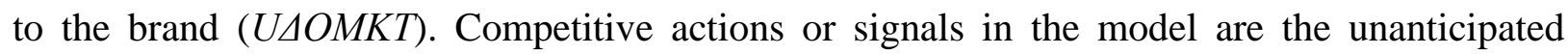
changes to competitive brand innovation (UACINN), competitive pioneering (CPION) and unanticipated changes to competitive advertising, promotions, customer liking and perceived quality ( $U \triangle C M K T)$. Finally, category variables (U $\triangle C A T$ ) include category size, category growth rate, category concentration and the market share of the firm in the category (to capture cannibalization effects) while $\varepsilon_{i t}$ is the error term. Note that we include the possibility of interactions for each marketing variable with both the innovation level (UAINN) and the pioneering nature of the product innovation $(P I O N)$. The unanticipated components are modeled either via survey data of analysts' expectations or via time-series extrapolations (Cheng and Chen 1997). This study follows the latter approach, using the residuals from a time-series model as the estimates of the unanticipated components.

In stock-return response models such as the above, a test of "value relevance" of unexpected changes to firm results and actions is a test for significance of the $\beta$ and $\gamma$ coefficients; significant values imply that these variables provide incremental information in

explaining stock returns. ${ }^{5}$ Empirically, we estimate using a fixed effects cross-sectional/timeseries panel model to control for unobserved brand and firm characteristics. We test for pooling versus estimating a fixed effects cross-sectional time-series panel model to evaluate for the significance of the cross-section effects using sums-of-squares F-test and the likelihood function using EViews 6.0 (2007, see User Guide II, p. 568 for details). Since we have multiple observations by firm (i.e. multiple brands of the same firm in up to six categories, as described in the data section below), we use SUR estimation to account for the contemporaneous correlations.

\section{Data and Variable Operationalization}

We focus on the 1996-2002 automobile industry's "big six:” Chrysler, Ford, General Motors, Honda, Nissan and Toyota, representing about $86 \%$ of the U.S. car market. Sales transaction data from J.D. Power \& Associates are available for a sizeable sample of dealerships in the major metropolitan areas in the United States. For the sales promotions, we use data from California dealerships, containing every new car sales transaction in a sample of 1,100 dealerships from October 1996 through June 2002. ${ }^{6}$ Each observation in the JDPA database contains the transaction date, manufacturer, model year, make, model, trim and other car information, 
transaction price, and sales promotions, operationalized as the monetary equivalent of all promotional incentives per vehicle. ${ }^{7}$ The vehicle information is aggregated to the brand, representing a brand's presence in each category (e.g., Chevrolet SUV). Table 2 clarifies the variables, their definitions, specific data sources, and the temporal as well as the cross-sectional aggregation of each variable. Importantly, we note that a certain brand may experience an innovation at several weeks during a year, because its (sub) models introduce their new versions at different times. We consider 53 brands in six major product categories: SUVs, minivans, midsize sedans, compact cars, compact pick-ups and full-size pick-ups, as shown in Table $3 .^{8}$

\section{--- Insert Tables 2 and 3 about here ---}

A second source of JDPA data is expert opinions on the innovation level of each vehicle redesign or introduction. We obtained these data from Pauwels et al. (2004) and point the reader to that paper for an extensive discussion of those data.

For the "pioneering” innovation variable, in line with the JDPA (1998) guidelines, JDPA experts rate innovativeness as pioneering or not. An example of level 1 for the premium car category is the 2001 Toyota Prius, the first gasoline-electric hybrid that could function as a versatile family car. Turning to the SUV category, an example of a pioneering innovation is the 1999 Lexus RX300, the first car-based SUV designed to compete in the luxury SUV segment. Table 4 provides specific illustrations of pioneering innovations.

--- Insert Table 4 about here ---

Another important set of JDPA data is the annual surveys on the 'APEAL' and 'Initial Quality' of cars, based on feedback from over 60,000 customers on the experience of the first months of ownership. The former is a customer-driven metric of "things gone right," which measures customer perceptions on the design, content, layout and performance of their new vehicles during the first three to seven months of ownership. We use this measure to operationalize 'customer liking'. The latter, our measure for 'perceived quality', is based on feedback from over 60,000 customers on the experience of the first 90 days of ownership, and measures the number of problems by each brand, essentially a measure of "things gone wrong” (see Table 2). ${ }^{9}$ A third source of data is advertising data from TNS Media Intelligence on monthly advertising expenditures by make and model in each of the six categories.

Stock returns are obtained from the Center for Research in Security Prices (CRSP). The Fama-French data source is Kenneth French's web site at Dartmouth. For firm-specific 
information and quarterly accounting information such as book value, revenues and net income, we use the Standard and Poor's COMPUSTAT database. Additionally, the COMPUSTAT dataset also provides monthly indices of the Consumer Price Index (CPI) which is used to deflate the monetary variables. To get weekly CPI data, we linearly interpolated the monthly numbers (see, e.g., Franses 2002). Table 5 provides the descriptive statistics for the measures that form the basis of the analysis in this paper.

--- Insert Table 5 about here ---

We choose the week as the time interval of analysis because (i) previous stock-return modeling studies have demonstrated that a few days suffice for studying product innovation (e.g., Chaney, Devinney and Winer 1991), (ii) weekly return data guard against noisy day-to-day (or even hourto-hour) day-trading patterns, and (iii) the product innovation variable is available at the weekly level.

Unanticipated Changes to Firm Actions and Results. Since the stock market reacts only to unexpected information, explanatory factors should only reflect unanticipated changes. In order to obtain a measure of unanticipated changes, we estimate a time series model and use the residuals as the estimates of unanticipated components. As an illustration, a first-order autoregressive model has been widely used to depict the time-series properties of firm performance such as earnings $\left(Y_{i t}\right)$ :

$Y_{i t}=\theta_{0}+\theta_{1} Y_{i t-1}+\eta_{i t}$

In the above equation, the coefficient $\theta_{l}$ is the first-order autoregressive coefficient depicting the persistence of the series. $\eta_{i t}$ provides a measure of unanticipated portion of $Y_{i t}$ and is used as the explanatory variable in the estimation of the stock-return response model in equation (2) (In other words, the residuals in equation (3) provide an estimate of $U \Delta Y_{i t}$ ).

\section{Empirical Results}

Table 6 shows the correlations among the variables. The variance inflation factors range from 1.18 to 1.72 , which is acceptable and suggests that multicollinearity amongst the variables is not an issue of concern.

--- Insert Table 6 about here ---

We first estimate the benchmark Fama-French model in equation (1), followed by the focal model equation (2). ${ }^{10}$ The stock-return models are statistically significant at $p<.05$ for both the 
benchmark Fama-French model as well as the focal model, including firm results and firm actions. We discuss, in turn, our main results on the benchmark Fama-French model, the Pauwels et al. (2004) model and the focal model as well as the robustness of the implied causality from marketing mix to stock market returns.

--- Insert Table 7 about here ---

\section{Results of the Benchmark Models}

Are stock returns affected by the four risk factors size $(S M B)$, the importance of intangibles $(H M L)$, risk class $(R m-R f)$ and momentum $(U M D)$ ? First, as shown in columns 3 and 4 , the benchmark Fama-French model is statistically significant at $p<.05$ with the adjusted R-squared of .154. The market-risk coefficient is positive and significant $(.308, p<.01)$ and different from 1.00, suggesting that the big-six automobile firms have below-average market risk. Indeed, consistent with the CAPM model and the Fama-French models, the coefficient for market risk dominates all other explanatory variables in our models in terms of t-values. The coefficient for size risk, $S M B$, is positive and significant $(.041, p<.05)$ while the coefficient for value risk is also positive and significant $(.302, p<.01)$. Thus, these results confirm well-established findings that (i) small caps and (ii) stocks with a high book-to-market ratio tend to do better than the market as a whole. Interestingly, the only variable that does not significantly explain stock returns in our data, momentum, represents a later addition to the four-factor model.

Pauwels et al. Variables. In columns 5 and 6 of Table 7, we report the results of the stock-return response model, adding the marketing variables of Pauwels et al. (2004). As for the FamaFrench factors, $S M B, H M L$ and $R m-R f$ remain significant. Moreover, the marketing actions regarding innovation and promotion, and their firm results regarding revenue and income, significantly affect stock returns over and above the Fama-French factors. In fact, the "marketing

+ finance" model explains twice as much variance in stock returns compared to the nested "finance only" model. Still, our richer focal model outperforms the nested Pauwels et al. (2004) benchmark. Therefore, we focus on discussing the results of the focal model below and return to the Pauwels et al. benchmark results in the Managerial Implications section for comparison purposes. 


\section{Focal Model Results}

The focal model, reported in Table 7 (columns 7 and 8), is statistically significant (F-value at $\mathrm{p}$ $<.05)$. The sums-of-squares F-test and the likelihood function test statistics for pooling versus fixed effects rejected the null that the fixed effects are redundant $(p<.05) .{ }^{11}$ Interestingly, the estimated effect of size ( $S M B)$ becomes statistically insignificant, indicating that the size effect is likely captured by the firm-specific marketing actions and results included in the focal modal. We tested for autoregressive conditional heteroskedasticity (ARCH) in the residuals using Engle’s Lagrange Multiplier ARCH test (Engle 1982; van Dijk, Franses and Lucas 1999) and fail to reject the null hypotheses of no $\operatorname{ARCH}(p<.01)$.

\section{Do Firm Results Drive Stock Returns?}

A key question on the firm results side is: Do firm revenue surprises and firm earnings surprises affect stock returns? As shown in Table 7 (columns 7 and 8), the impact of unexpected changes to revenue, or top-line performance, on stock returns is positive and significant $(.544, p<.05)$. Similarly, the impact of unanticipated changes to income, or bottom-line performance, on stock returns is positive and significant $(2.511, p<.01)$. The size of the estimate is similar to that reported previously, e.g. Kormendi and Lipe (1987), who report a coefficient of 3.38. These two effects are consistent with the extensive accounting and finance literature (e.g., Kothari 2001) that has documented the information content of revenues and earnings measures. When an unanticipated change in firm results (e.g., earnings) occurs, investors view it as containing information not only about changes in current-term results but about future-term prospects as well. This information induces stock market participants to update their expectations about the firm’s discounted future cash flows and revise stock price accordingly.

\section{Do Firm Actions Drive Stock Returns?}

The key question on the firm actions side is: Do firm action surprises affect stock returns?

New-to-the-Company Innovations. Confirming $\mathrm{H}_{1 \mathrm{a}}$, new-to-the-company innovations generally have a positive and significant impact (.546, $p<.01)$. This effect is U-shaped (see Figure 2) in the level of innovation, with a strong preference for new market entries/level 5 innovations (.981, $p<.01$ ) over minor updates/level 1 innovations (.546, $p<.01$ ), lending support to $\mathrm{H}_{1 \mathrm{~b}}$. As for competitive new-to-the-company innovations, the main effect of such innovations on stock 
returns is not significant. Thus, it appears that competitive innovations have no incremental information content to investors regarding the focal firm, unless they are new-to-the-market.

\section{--- Insert Figure 2 about here ---}

New-to-the-Market Innovations. Pioneering innovations have a positive and significant impact on stock returns $\left(3.304, p<.01\right.$ ), consistent with $\mathrm{H}_{2 \mathrm{a}}$. Importantly, the advent of pioneering innovations dominates all other explanatory variables in the models. As such, pioneering innovations reflect information that affects financial markets' expectations about the firm's future financial performance. Likewise, pioneering innovations of competitors have a significant negative impact on stock returns $(-.882, p<.05)$.

Advertising Support. As noted earlier, we test both the main and the interaction effects of marketing support. Advertising has positive and significant effects on stock returns $(.045, p<.05)$. Advertising support for new-to-the-company innovations as well as pioneering innovations increases the stock market returns of these innovations (.055, $p<.05$ and .812, $p<.01)$, in support of $\mathrm{H}_{3 \mathrm{a}}$ and $\mathrm{H}_{3 \mathrm{~b}}$. In other words, advertising support for new products (via the interaction effect) has a positive stock-return impact above and beyond general-purpose advertising (i.e. the main advertising effect). Since advertising and innovation are at the brand (or vehicle model) level, advertising support will draw consumer attention to the brand's innovation to subsequently drive customer traffic and new product sales to the dealer. From a practical perspective, most brand advertising at the time of a new product launch in the auto industry tends to focus on the innovation itself (e.g., the 1999 Odyssey's folding-flat rear seat, the Lexus RX's smooth drive, etc.). Overall, our results suggest that the innovation effects are enhanced by advertising support, as investors look beyond the advertising expense (which reduces immediate profits) and reward the signal of product support that the brand provides by advertising. Advertising support for pioneering innovations appears especially effective, in line with $\mathrm{H}_{3 c}$ : Marketing communication works best when managers have something truly new to offer to and communicate with consumers.

Price Promotions. Turning to price promotions, we find that the main effect of these incentives on stock returns is not significant. Thus, even though promotions are known to be revenue- and profit-enhancing in the short run, investors do not reward them. More importantly, we find a 
significant negative interaction effect $(-.002, p<.05)$ for promotions with innovations, in support of $\mathrm{H}_{4}$. Thus, while advertising support is interpreted as a sign of strength, price promotions may be seen as a signal that an innovation is weak by investors judging the innovation's impact on future cash flows.

Customer Liking and Perceived Quality. With respect to the brand's customer liking and perceived quality, we note that main effects are not significant. This is not surprising since, when there is no new product nor a change in the existing product, we would not expect any change in the brand's liking and quality, and in turn, in stock market returns. The effect of new-product introductions that enjoy more positive scores on customer liking is in the expected direction $\left(\mathrm{H}_{5}\right)$; however, it does not reach traditional significance levels. New-product introductions that enjoy more positive consumer perceptions of quality have systematically higher stock returns (.021, $\mathrm{p}$ $<.01$ ), in support of $\mathrm{H}_{6}$. Our results suggest that improvements in consumer appraisal in terms of perceived quality, particularly for new products, translate into better investor appraisal of firm performance.

\section{Do Category Characteristics Drive Stock Returns?}

Category size and category growth rate have significant interaction effects with product innovations. First, new-product introductions have a larger stock-return impact in large versus small categories $(.220, p<.01)$. Second, the category growth rate has a significant positive influence $(.618, p<.01)$ on stock returns from new-product introductions. This finding is consistent with the forward-looking nature of investment behavior; i.e., investors reward firms that target high-growth rate categories with new-product introductions as they offer the potential of higher sales and financial performance. Moreover, the returns from innovating grow as the category grows; such growth tends to be rewarded all the more by investors. ${ }^{12}$

\section{Robustness Test of Endogeneity}

The paper's central hypothesis is that marketing-mix activity such as product innovation and advertising improves the outlook on cash flows and hence improves stock returns, above and beyond the known impact of other important variables such as the firm's net operating income. However, one could also construct an argument in favor of the reverse effect; e.g., firms' innovations and advertising levels are based, in part, on their observed stock returns. 
Specifically, marketers may want to incorporate investor behavior in their actions, realizing that there may be a "reverse causality" between marketing and stock returns (Markovitch, Steckel and Yeung 2005).

Under the reverse-causation scenario, firm actions (e.g., innovations and advertising levels) are endogenously determined. Therefore, we tested for the presence of endogeneity using the Hausman-Wu test (Davidson and MacKinnon 1993; Gielens and Dekimpe 2001). The procedure is implemented as follows for each potentially endogenous variable: In the test equation, we include both the variable and its instruments, which are derived as the forecasts from an auxiliary regression linking the variable to the other control variables. A $\chi^{2}$-test on the significance of these instruments then constitutes the exogeneity test. None of these tests revealed any violation of the assumed exogeneity of the right-hand-side variables (using a significance level of $p<.05$ ), indicating that the model specification is robust to this issue.

\section{Managerial Implications}

In order to better appreciate the managerial meaning of these results, we juxtapose the consequences of the variables largely under managerial control: new-product introductions, the pioneering status of the new-product introduction, advertising support, promotion support for new-product introductions, and improvements in customer liking and perceived quality of newproduct introductions. The first two variables are related to innovation characteristics, i.e. value creation; the next two involve marketing support, i.e. value communication; and the last two variables involve both value creation and value communication. Therefore, the comparison of these effects may provide valuable input for resource-allocation decisions in the new-product process. Specifically, we calculate the stock-return impact of: (i) a new-product introduction by itself, (ii) introducing a pioneering innovation, (iii) increasing advertising support for a newproduct introduction or for a pioneering innovation by $\$ 1$ million, (iv) increasing promotional incentives for a new-product introduction by $\$ 1000$, (v) increasing customer liking for a newproduct introduction, and (vi) increasing the perceived quality for a new-product introduction. Of these effects, only (i) and (iv) have been addressed previously in Pauwels et al. (2004). Table 8 reports the effect sizes and also highlights the new managerial insights over Pauwels et al. (2004) obtained by comparing columns 2 and 3. See Figure 3 for a graphical comparison summary of marketing variables' impact on stock returns. 
First, the stock-return impact is U-shaped with the innovation level, with a preference for new-market entries (.98\%) over minor updates (.55\%). By comparison, Chaney, Devinney and Winer (1991) found a stock-market impact for new-product announcements of about .75\%. These results support the interpretation that investors look beyond current financial returns and consider spill-over innovation benefits, which may include increased revenues from opening up whole new markets and reduced costs from applying the innovation technology to different vehicles in the manufacturer's fleet (Sherman and Hoffer 1971). While a new-product introduction generates only modest stock-return gains, the gain generated by a pioneering new product is much higher at $4.28 \%$. Thus, the impact of introducing a pioneering innovation on stock returns is about seven times higher than that of introducing a minor update.

Furthermore, an incremental outlay of $\$ 1$ million in advertising support of an innovation generates up to $.10 \%$ in stock returns, but up to $.91 \%$ gains for advertising support of a pioneering innovation. Note that these gains occur in addition to the direct sales and profit impact of such advertising support. The reverse is true for promotional support for new-product introductions and pioneering innovations, as these are negative (-.20\%) in terms of stock-return impact. Finally, improvements in perceived quality score by 100 points or a $45 \%$ improvement relative to the sample average score of 221, as shown in Table 5, results in a stock-return impact of $2.10 \%$. In contrast, financial markets do not seem to incrementally value improvements in customer liking scores for new-product introductions. The reason for this difference may reside in the sampling of only current owners of the car, which logically like its features (hence the low informational value of customer liking, over and above the informational value of measures such as sales and earnings, to future company cash flows), but may or may not have experienced problems (hence the high informational value of perceived quality to future company cash flows, which likely suffer from bad word-of-mouth and poor retention in case of negative perceived quality). 


\section{Conclusions}

This paper has investigated the impact on stock returns of new-product introductions and the associated marketing investments. We postulated several hypotheses in this regard, centered on the role of marketing mix in enhancing, accelerating and stabilizing cash flows for the firm, and/or increasing its residual value. These hypotheses were tested using stock-return response modeling on six years of weekly automotive data.

We conclude, first, that new-product introductions have positive post-launch effects on stock returns. These effects are stronger in larger, high-growth categories. In addition, the stockreturn benefits of pioneering (new-to-the-market) innovations are seven times larger than those that are merely new-to-the-company. This finding contrasts with the reality that managers favor the rollout of frequent incremental innovations over that of fewer, more fundamental innovations. Such incremental innovations are less costly and risky, which is important in light of the multi-billion dollar cost of new-car platforms (White 2001). Our research controls for these costs empirically by including firm revenue and earnings performance as drivers of stock returns. However, we do not claim to have fully captured the financial and time investment of innovation development. Companies may compare our reported findings with their internal data on project costs to help decide the extent to which they should aim for pioneering innovations.

Second, the marketing of these innovations plays an equally important role. We find that the stock-return impact of new-product introductions is higher when they are backed by substantial advertising investments. In other words, communicating the differentiated added value to consumers yields higher firm-value effects of innovations, especially for pioneering innovations. In contrast, promotional incentives do not increase firm-value effects of newproduct introductions, as they may signal an anticipated weakness in demand for the new product. Third, the stock-return impact of new-product introductions is higher for innovations with higher levels of perceived quality.

This study has several limitations that provide interesting avenues for future research. First, we analyzed only one industry, albeit an important one in which product innovation, advertising and consumer incentives are a major part of the marketing mix. Therefore, we emphasize that the paper's findings on stock drivers pertain to the automobile industry, and a validation of the results in this paper to other industries is an important area for future research. Second, we did not consider specific launch strategy or innovation-process measures, both of 
which have been researched extensively in past literature. Third, the focus in this study is on post-launch effects of innovations, including pioneering innovations on stock-market returns. As such, we focus on product innovations that made it to market while products that do not make it to the market are censored out of the data. Future research using data on the development costs of innovation, including those that do not make it to market, would enable a direct assessment of the stock-return impact of pre-launch effects of innovation. Fourth, we do not have data on advertising copy, and hence, we leave the issue of advertising copy and effectiveness of newproduct advertising to future research. Finally, we leave the issues of investigating the presence or absence of threshold effects and reciprocal causation of advertising on stock market performance for future research. 
FIGURE 1

\section{Conceptual Framework}

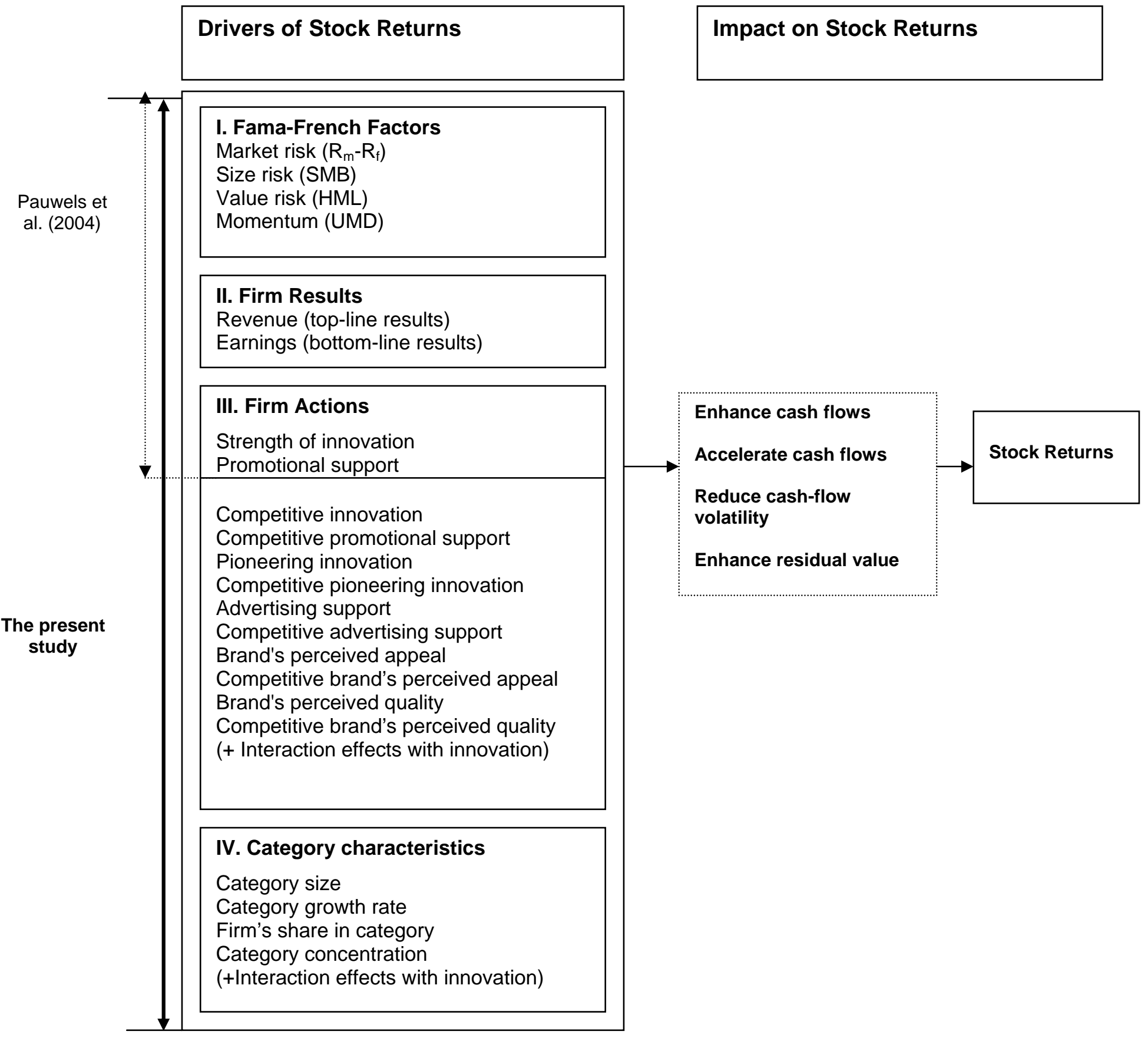


FIGURE 2

Stock Returns and New-to-the-Company Innovations

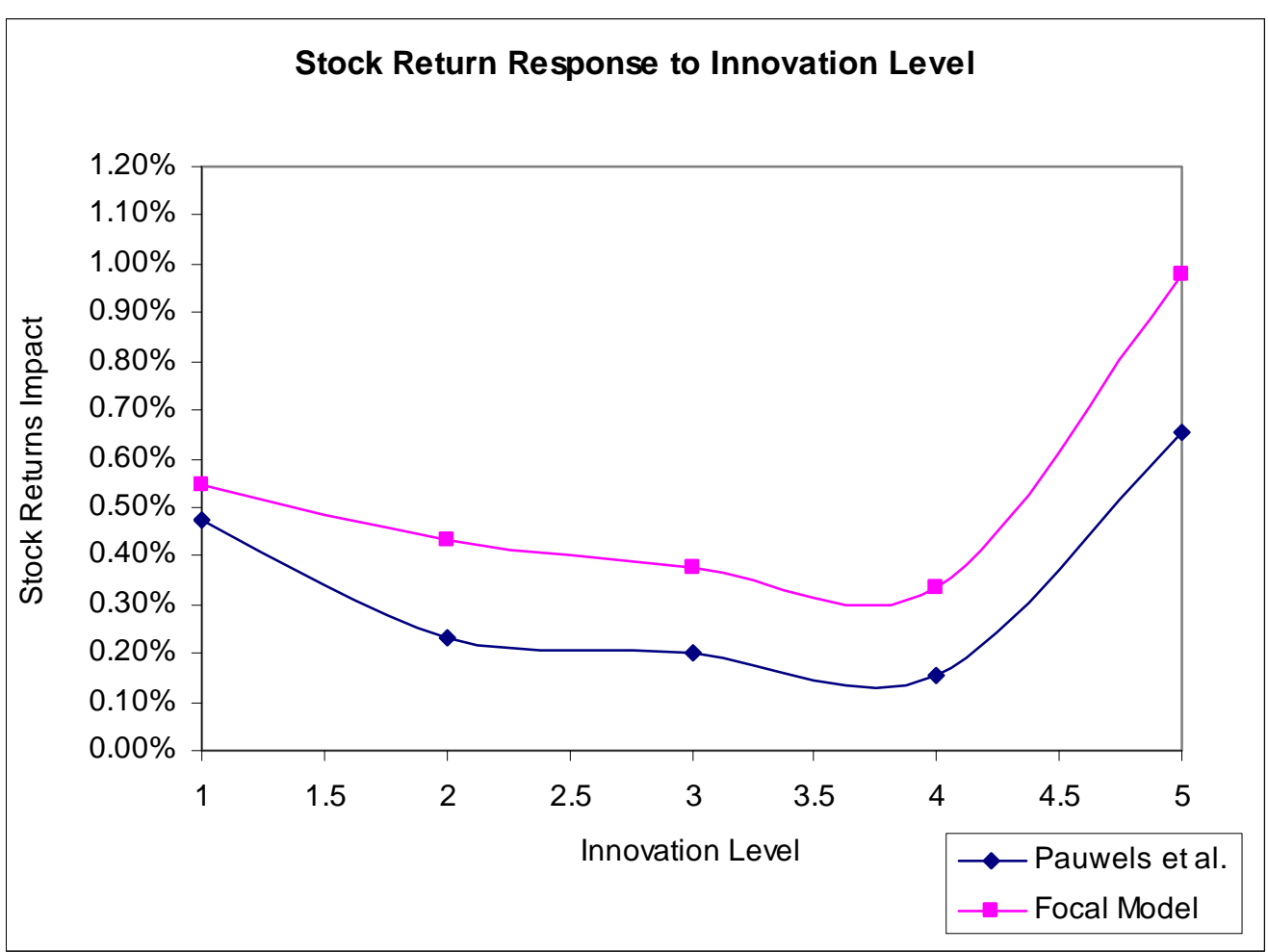


FIGURE 3

Marketing Impact on Stock Returns

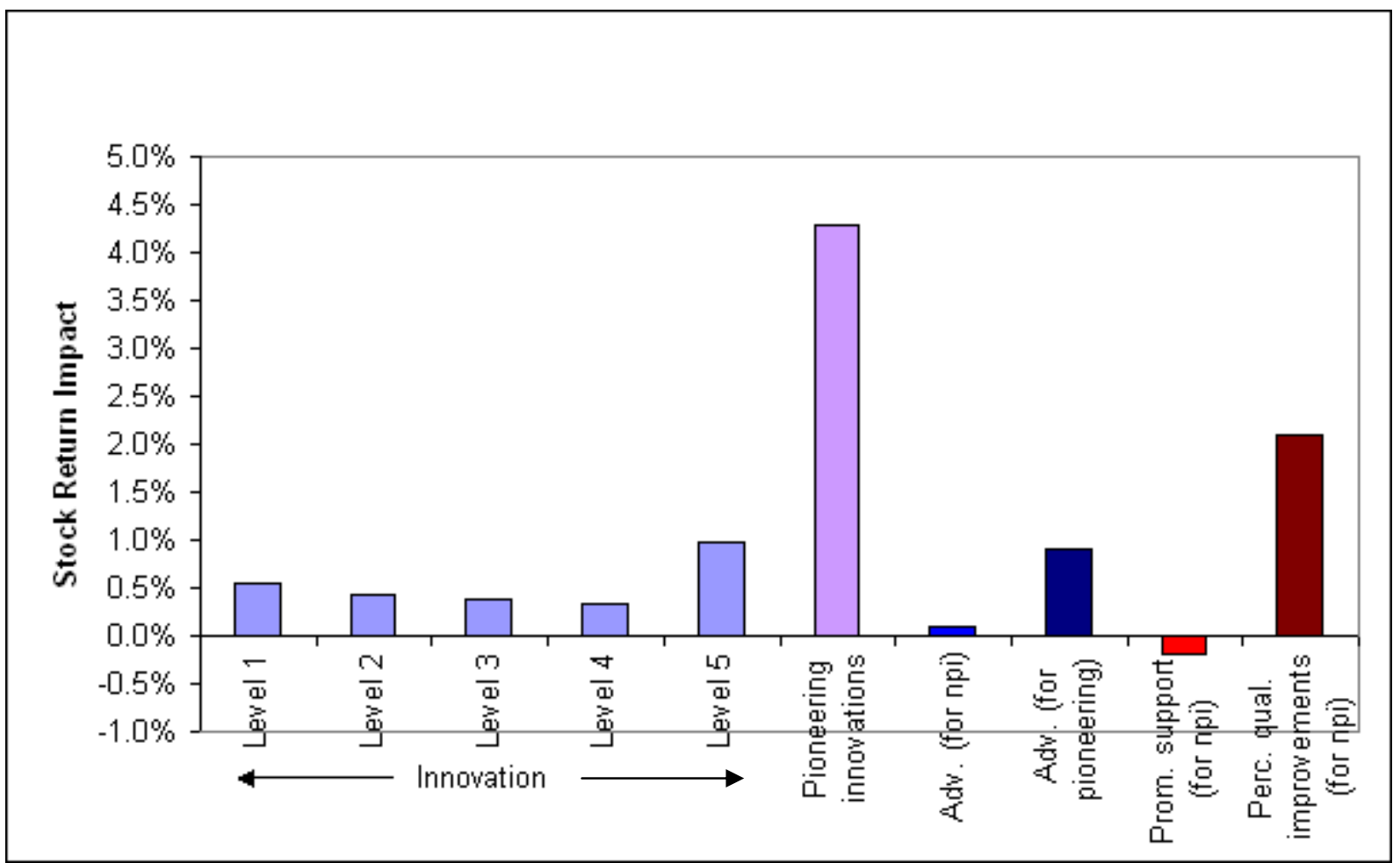


TABLE 1

Marketing Drivers of Stock Returns

\begin{tabular}{|c|c|c|c|c|c|}
\hline Hypotheses \& Drivers & $\begin{array}{l}\text { Enhancing } \\
\text { cash flows }\end{array}$ & $\begin{array}{l}\text { Accelerating } \\
\text { cash flows }\end{array}$ & $\begin{array}{l}\text { Reducing } \\
\text { volatility of } \\
\text { cash flows }\end{array}$ & $\begin{array}{l}\text { Residual } \\
\text { value }\end{array}$ & $\begin{array}{l}\text { Net effect on } \\
\text { unexpected } \\
\text { stock returns }\end{array}$ \\
\hline $\mathrm{H}_{1}$ : Innovation level & + & ? & + & + & ++ \\
\hline $\mathrm{H}_{2}$ : Pioneering innovation & + & ? & ? & + & ++ \\
\hline $\mathrm{H}_{3}$ : Advertising support & + & + & ? & + & ++ \\
\hline $\mathrm{H}_{4}$ : Promotional support & $+/-$ & + & ? & - & - \\
\hline $\mathrm{H}_{5}$ : Customer liking & + & ? & + & + & ++ \\
\hline $\mathrm{H}_{6}$ : Perceived quality & + & ? & + & + & ++ \\
\hline
\end{tabular}


TABLE 2

Data -Variable Definitions

\begin{tabular}{ll} 
Variable & Definition \\
\hline $\begin{array}{l}\text { Dependent Variable } \\
\text { Stock Returns }\left(R_{i t}\right)\end{array}$ & (Price $_{\mathrm{t}}+$ Dividend $_{\mathrm{t}}-$ Price $\left._{\mathrm{t}-1}\right) /\left(\right.$ Price $\left._{\mathrm{t}-1}\right)$ \\
$\begin{array}{l}\text { Fama \& French Factors } \\
\text { Market Risk }(R m-R f)\end{array}$ & $\begin{array}{l}\text { Rm is the average market rate of return, and Rf is the risk-free } \\
\text { rate of return } \\
\text { Difference of returns on a value-weighted portfolio of small } \\
\text { stocks and the return on big stocks }\end{array}$ \\
Difference of returns on a value-weighted portfolio of high \\
and low book-to-market stocks
\end{tabular}

Source

\section{Firm Actions}

Firm Income

Firm income, scaled by dividing by firm assets, is the earnings of firm $\mathrm{i}$ in week $\mathrm{t}$

Firm Revenue

Firm revenue, scaled by dividing by firm assets, is the revenue of firm $\mathrm{i}$ in week $\mathrm{t}$

Seasonal and Holiday Variables

It is set $=1$ for one week prior to, during the week of the event, and one week following the event, and $=0$ otherwise, around the following holidays: Labor Day weekend, Memorial Day weekend and the end of each quarter

Product Innovation

Brand innovation variable for brand $\mathrm{j}$ in category $\mathrm{k}$ for firm $\mathrm{i}$ at time $t$ is defined as the maximum of the innovation variable for all vehicle model transactions in that week, as in Pauwels et al. (2004). This variable is used to create the innovation variables that measure each innovation level from 1 to 5 .

Competitive Product Innovation

Market-share weighted average of the product innovation of all the other brands (other than the focal brand) in the category

Pioneering Innovation

A dummy variable indicates whether the JDPA experts rate innovations as pioneering (=1) or not. This variable is set to 1 in the week of introduction of the pioneering innovation and is set to 0 , otherwise

Competitive Pioneering Innovation

This variable is set to 1 in the week of introduction of the pioneering innovation of the other brands (other than the focal brand in the category) and is set to 0 , otherwise

Advertising Support

Competitive Advertising Support

Promotional Support

Advertising expenditure in millions of dollars for brand $\mathrm{j}$ in category $\mathrm{k}$ for firm $\mathrm{i}$ at time $\mathrm{t}$, scaled by firm assets

Market-share weighted average of the advertising support of all the other brands (other than the focal brand) in the category The monetary equivalent of promotional incentives for brand $j$ in category $\mathrm{k}$ for firm i at time t; the brand-level calculated by the market-share weighted average of the incentives for all models of brand $\mathrm{j}$ in category $\mathrm{k}$, scaled by firm assets
CRSP

Kenneth French's Website

\section{COMPUSTAT}

COMPUSTAT

JDPA Expert opinions; JDPA weekly transactions data

JDPA Expert opinions; JDPA weekly transactions data JDPA Expert Opinions

JDPA Expert Opinions

TNS Media Intelligence

TNS Media Intelligence

JDPA weekly transactions data 
Competitive Promotional Support

Brand's Customer Liking

Competitive Customer Liking

Brand’s Perceived Quality

Competitive Perceived Quality

\section{Category Control Variables}

\author{
Category Size \\ Category Growth Rate
}

Market Share

Category Concentration
Market-share weighted average of the promotional support of all the other brands (other than the focal brand) in the category

The brand level measure is calculated as the market-share weighted average of the perceived 'APEAL' rating of the models for brand $\mathrm{j}$ in category $\mathrm{k}$ at time $\mathrm{t}$. This is a customerdriven measure of "things gone right," which measures customer perceptions on the design, content, layout and performance of their new vehicles during the first three to seven months of ownership

Market-share weighted average of the perceived 'APEAL' of all the other brands (other than the focal brand) in the category

The brand level measure is calculated as the market-share weighted average of the perceived quality of the models for brand $\mathrm{j}$ in category $\mathrm{k}$ at time t. This survey, based on feedback from over 60,000 customers on the experience of the first 90 days of ownership, measures the number of problems by each brand and is a measure of "things gone wrong." Hence, the latter IQS measure is negatively signed to obtain the perceived quality metric above

Market-share weighted average of the perceived quality of all the other brands (other than the focal brand) in the category

Category size is the total sales in week t for category $\mathrm{k}$

The metric of interest is obtained as the ratio of category growth rate of category $\mathrm{k}$ to total growth rate for all auto sales, to obtain a measure of relative attractiveness of a category

Market share of the firm i in category $\mathrm{k}$ in week $\mathrm{t}$

Category concentration is the sum of the market share of the top-three brands within the category $\mathrm{k}$ in week $\mathrm{t}$
JDPA weekly transactions data

JDPA survey data for the 'APEAL' measure; JDPA weekly transactions data

JDPA survey data for the 'APEAL' measure; JDPA weekly transactions data

JDPA Initial Quality Survey for the 'APEAL' measure; JDPA weekly transactions data

JDPA Initial Quality Survey for the 'APEAL' measure; JDPA weekly transactions data

JDPA weekly transactions data

JDPA weekly transactions data

JDPA weekly transactions data

JDPA weekly transactions data 
TABLE 3

Brands of the Six Leading Car Manufacturers

\begin{tabular}{|c|c|c|c|c|c|c|c|}
\hline Category & Brands & Chrysler & Ford & $\begin{array}{l}\text { General } \\
\text { Motors }\end{array}$ & Honda & Nissan & Toyota \\
\hline Sport Utility Vehicles & 15 & $\begin{array}{l}\text { Dodge, } \\
\text { Jeep }\end{array}$ & $\begin{array}{l}\text { Ford } \\
\text { Lincoln }\end{array}$ & $\begin{array}{l}\text { Chevrolet, } \\
\text { Cadillac, } \\
\text { GMC, } \\
\text { Oldsmobile, } \\
\text { Buick }\end{array}$ & $\begin{array}{l}\text { Honda } \\
\text { Acura }\end{array}$ & $\begin{array}{l}\text { Nissan } \\
\text { Infiniti }\end{array}$ & $\begin{array}{l}\text { Toyota } \\
\text { Lexus }\end{array}$ \\
\hline Minivans & 9 & $\begin{array}{l}\text { Dodge, } \\
\text { Chrysler }\end{array}$ & $\begin{array}{l}\text { Ford } \\
\text { Mercury }\end{array}$ & $\begin{array}{l}\text { Chevrolet, } \\
\text { Oldsmobile }\end{array}$ & Honda & Nissan & Toyota \\
\hline Premium Mid-size Cars & 9 & Chrysler & $\begin{array}{l}\text { Ford } \\
\text { Mercury }\end{array}$ & $\begin{array}{l}\text { Chevrolet } \\
\text { Oldsmobile, } \\
\text { Buick }\end{array}$ & Honda & Nissan & Toyota \\
\hline Premium Compact Cars & 8 & Chrysler & Ford & $\begin{array}{l}\text { Chevrolet, } \\
\text { Pontiac } \\
\text { Saturn }\end{array}$ & Honda & Nissan & Toyota \\
\hline Compact Pick-ups & 6 & Dodge & Ford & $\begin{array}{l}\text { Chevrolet, } \\
\text { GMC }\end{array}$ & & Nissan & Toyota \\
\hline Full-size Pick-ups & 7 & Dodge & $\begin{array}{l}\text { Ford } \\
\text { Lincoln }\end{array}$ & $\begin{array}{l}\text { Chevrolet, } \\
\text { GMC, } \\
\text { Cadillac }\end{array}$ & & & Toyota \\
\hline
\end{tabular}


TABLE 4

\section{Examples of Pioneering Innovations}

\begin{tabular}{lll}
\hline Category & Pioneering Innovation & Description \\
\hline Compact Car & 2001 Toyota Prius & First gasoline-hybrid \\
Truck & 2002 Chevrolet Avalanche & $\begin{array}{l}\text { Unique convertible cab system to transform from a 5- } \\
\text { passenger sport-utility into a standard cab pick-up }\end{array}$ \\
Truck & 2002 Lincoln Blackwood & $\begin{array}{l}\text { Introduced as a cross between a luxury SUV and a } \\
\text { pick-up truck }\end{array}$ \\
SUV & 1999 Lexus RX 300 & $\begin{array}{l}\text { First car-based SUV in the luxury segment } \\
\text { 1999 Honda Odyssey }\end{array}$ \\
\hline
\end{tabular}


TABLE 5

Characteristics of the Six Leading Car Manufacturers 1996- 2002**

\begin{tabular}{lllllll}
\hline Characteristic & Ford & $\begin{array}{l}\text { General } \\
\text { Motors }\end{array}$ & Chrysler & Honda & Nissan & Toyota \\
& & & & & \\
\hline U.S. Market Share & $21 \%$ & $28 \%$ & $15 \%$ & $8 \%$ & $4 \%$ & $10 \%$ \\
Market Capitalization (\$ billions) & 48.6 & 36.7 & 44.3 & 34.1 & 18.5 & 112.2 \\
Quarterly Firm Earnings (\$M) & 1,570 & 1,040 & 845 & 530 & 750 & 1,015 \\
Quarterly Firm Revenue (\$M) & 37,025 & 40,600 & 29,080 & 12,090 & 10,765 & 25,220 \\
Stock Market Returns (\%) & $-.077 \%$ & $.086 \%$ & $.199 \%$ & $-.063 \%$ & $.102 \%$ & $.165 \%$ \\
Brand Advertising (yearly in \$M) & 720 & 1430 & 660 & 250 & 290 & 400 \\
\# of New-Product Introductions & 113 & 93 & 67 & 42 & 24 & 56 \\
(Levels 1-5) & & & & & & 120 \\
Sales Promotions per Vehicle (\$) & 390 & 640 & 640 & 25 & 200 & 613 \\
Customer Liking Score & 603 & 588 & 644 & 601 & 626 & 226 \\
Perceived Quality Score & 203 & 248 & 187 & 232 & 230 & \\
\hline
\end{tabular}

Notes: The values reported above are the sample mean of the time series. The exception is new-product introductions where we report the total number of new-product introductions. 
TABLE 6

Inter-Correlations Among the Variables

\begin{tabular}{|c|c|c|c|c|c|c|c|c|c|c|c|c|c|c|c|c|c|c|c|}
\hline Variables & 1 & 2 & 3 & 4 & 5 & 6 & 7 & 8 & 9 & 10 & 11 & 12 & 13 & 14 & 15 & 16 & 17 & 18 & 19 \\
\hline 1. $\quad$ Stock Return & 1.00 & & & & & & & & & & & & & & & & & & \\
\hline 2. U $\Delta$ Revenue & .04 & 1.00 & & & & & & & & & & & & & & & & & \\
\hline 3. U $\Delta$ Earnings & .04 & .01 & 1.00 & & & & & & & & & & & & & & & & \\
\hline 4. U $\Delta$ Innovation & .02 & -.01 & .00 & 1.00 & & & & & & & & & & & & & & & \\
\hline $\begin{array}{l}\text { 5. U } \Delta \text { Comp. } \\
\text { Innovation }\end{array}$ & .10 & .04 & -.01 & .00 & 1.00 & & & & & & & & & & & & & & \\
\hline 6. Pioneering & .03 & .00 & .00 & .00 & -.02 & 1.00 & & & & & & & & & & & & & \\
\hline 7. Comp. Pioneering & -.05 & .00 & .01 & .01 & -.05 & .00 & 1.00 & & & & & & & & & & & & \\
\hline 8. U UAdvertising & .07 & .11 & .00 & .01 & .11 & .00 & -.01 & 1.00 & & & & & & & & & & & \\
\hline $\begin{array}{l}\text { 9. U } \Delta \text { Comp. } \\
\text { Advertising }\end{array}$ & .06 & .08 & .00 & .01 & .13 & .00 & .06 & .25 & 1.00 & & & & & & & & & & \\
\hline 10. U $\Delta$ Promotions & -.05 & -.03 & .00 & -.02 & -.02 & -.01 & -.02 & .00 & .01 & 1.00 & & & & & & & & & \\
\hline $\begin{array}{l}\text { 11. U } \Delta \text { Comp. } \\
\text { Promotions }\end{array}$ & .01 & -.09 & .03 & -.02 & -.03 & -.01 & .03 & -.07 & -.06 & .01 & 1.00 & & & & & & & & \\
\hline 12. U UCustomer Liking & .01 & -.01 & -.01 & .00 & .01 & .01 & -.01 & -.05 & -.02 & .01 & .02 & 1.00 & & & & & & & \\
\hline 13. U $\Delta$ Comp. Liking & -.07 & .03 & -.07 & .01 & .06 & .00 & -.01 & .04 & .08 & .00 & -.01 & .00 & 1.00 & & & & & & \\
\hline $\begin{array}{l}\text { 14. U } \Delta \text { Perceived } \\
\text { Quality }\end{array}$ & .02 & -.01 & -.01 & .02 & -.01 & .00 & -.01 & -.01 & -.03 & .01 & .01 & .46 & .00 & 1.00 & & & & & \\
\hline 15. U $\Delta$ Comp. Quality & .02 & .00 & -.01 & .00 & .15 & .03 & -.02 & .00 & -.02 & .00 & .03 & -.06 & .03 & -.03 & 1.00 & & & & \\
\hline 16. U $\Delta$ Category Size & .00 & -.03 & -.01 & -.03 & .03 & -.03 & -.04 & -.10 & -.03 & .00 & .10 & .01 & .01 & -.01 & .01 & 1.00 & & & \\
\hline 17. U $\Delta$ Category Growth & .00 & -.03 & .00 & -.02 & .03 & -.03 & -.04 & -.10 & -.02 & -.01 & .10 & -.01 & .01 & -.03 & -.03 & .92 & 1.00 & & \\
\hline 18. U $\Delta$ Firm's Share & -.03 & -.01 & .09 & -.02 & .01 & -.08 & -.03 & -.04 & .00 & -.01 & -.02 & .03 & -.02 & .03 & .00 & .04 & .03 & 1.00 & \\
\hline 19. U $\Delta$ Concentration & .02 & .02 & .05 & .02 & .00 & -.01 & -.03 & .03 & .00 & .01 & .00 & .01 & -.07 & -.03 & .00 & .03 & .07 & .03 & 1.00 \\
\hline
\end{tabular}

Correlations are presented as Pearson correlation coefficients and are modest. 
TABLE 7

Drivers of Stock Returns

\begin{tabular}{|c|c|c|c|c|c|c|c|}
\hline \multirow[t]{2}{*}{ Variables } & Hyp. & Estimate & Std. Error & Estimate & Std. Error & Estimate & Std. Error \\
\hline & & \multicolumn{2}{|c|}{$\begin{array}{l}\text { Fama-French Variables } \\
\text { Model } 1\end{array}$} & \multicolumn{2}{|c|}{$\begin{array}{l}\text { Pauwels et al. Variables } \\
\text { Model } 2 \text {-partial }\end{array}$} & \multicolumn{2}{|c|}{$\begin{array}{l}\text { Focal Model } \\
\text { Model } 2 \text { - full }\end{array}$} \\
\hline \multicolumn{8}{|l|}{ Fama-French 4 Factors } \\
\hline Constant & & -.010 & .035 & -.077 & .086 & .232 & .427 \\
\hline $\mathrm{R}_{\mathrm{m}}-\mathrm{R}_{\mathrm{f}}$ & & $.308 *$ & .017 & $.323 *$ & .085 & $.350 *$ & .020 \\
\hline SMB & & $.041^{* *}$ & .019 & $.048 * *$ & .024 & .059 & .039 \\
\hline HML & & $.302 *$ & .026 & $.323^{*}$ & .030 & $.373 *$ & .034 \\
\hline UMD & & .051 & .036 & .038 & .038 & .046 & .041 \\
\hline \multicolumn{8}{|l|}{ Firm Results } \\
\hline U $\Delta$ Revenue & & & & $.468 * *$ & .224 & $.544 * *$ & .261 \\
\hline U $\Delta$ Earnings & & & & $2.406 *$ & .811 & $2.511^{*}$ & .802 \\
\hline $\mathrm{U} \Delta$ Revenue $* \mathrm{U} \Delta$ Innovation & & & & 1.115 & .678 & .118 & .077 \\
\hline $\mathrm{U} \Delta$ Earnings $* \mathrm{U} \Delta$ Innovation & & & & $2.596 * *$ & 1.133 & $1.468 *$ & .519 \\
\hline \multicolumn{8}{|l|}{ Firm Actions } \\
\hline U $\Delta$ Innovation - Level 1 & $\mathrm{H} 1$ & & & $.473^{*}$ & .140 & $.546 *$ & .146 \\
\hline U $\Delta$ Innovation - Level 2 & $\mathrm{H} 1$ & & & $.231 * *$ & .113 & $.432 *$ & .137 \\
\hline U $\Delta$ Innovation - Level 3 & H1 & & & .202 & .125 & .375 & .272 \\
\hline U $\Delta$ Innovation - Level 4 & $\mathrm{H} 1$ & & & $.157 * *$ & .078 & $.335 *$ & .103 \\
\hline U $\Delta$ Innovation - Level 5 & H1 & & & $.654^{*}$ & .223 & $.981 *$ & .420 \\
\hline $\mathrm{U} \Delta$ CCompetitive Innovation & & & & & & .003 & .047 \\
\hline Pioneering & $\mathrm{H} 2$ & & & & & $3.304 *$ & 1.022 \\
\hline CCompetitive Pioneering & & & & & & $-.882 * *$ & .425 \\
\hline $\mathrm{U} \Delta$ Advertising & & & & & & $.045^{* *}$ & .022 \\
\hline Us CCompetitive Advertising & & & & & & -.127 & .128 \\
\hline $\mathrm{U} \Delta$ Advertising * U $\Delta$ Innovation & НЗа & & & & & $.055^{* *}$ & .023 \\
\hline $\mathrm{U} \Delta$ CCompetitive Advertising $* \mathrm{U} \Delta$ & & & & & & .182 & .170 \\
\hline \multicolumn{8}{|l|}{ Innovation } \\
\hline $\mathrm{U} \Delta$ Advertising $*$ Pioneering & H3b,c & & & & & $.812^{*}$ & .329 \\
\hline $\mathrm{U} \Delta$ Price Promotions & & & & $-.002 *$ & .000 & -.005 & .003 \\
\hline U $\Delta$ CCompetitive Promotions & & & & & & -.004 & .004 \\
\hline $\mathrm{U} \Delta$ Price Promotions $* \mathrm{U} \Delta$ Innovation & $\mathrm{H} 4$ & & & $-.002 *$ & .000 & $-.002 * *$ & .000 \\
\hline $\mathrm{U} \Delta$ CCompetitive Promotions $* \mathrm{U} \Delta$ & & & & & & .017 & .111 \\
\hline \multicolumn{8}{|l|}{ Innovation } \\
\hline U $\Delta$ Promotions * Pioneering & & & & & & -.018 & .080 \\
\hline U $\Delta$ Liking & & & & & & .001 & .001 \\
\hline U $\Delta$ CCompetitive Liking & & & & & & .019 & .016 \\
\hline U $\Delta$ Liking * U $\Delta$ Innovation & H5 & & & & & .029 & .019 \\
\hline $\mathrm{U} \Delta$ CCompetitive Liking* U $\Delta$ & & & & & & -.017 & .017 \\
\hline \multicolumn{8}{|l|}{ Innovation } \\
\hline U $\Delta$ Liking * Pioneering & & & & & & .191 & .190 \\
\hline $\mathrm{U} \Delta$ Quality & & & & & & .011 & .009 \\
\hline U $\Delta$ CCompetitive Quality & & & & & & $-.014 *$ & .004 \\
\hline $\mathrm{U} \Delta$ Quality * U $\Delta$ Innovation & H6 & & & & & $.021 *$ & .002 \\
\hline U $\Delta$ CCompetitive Quality* U $\Delta$ & & & & & & -.257 & .251 \\
\hline \multicolumn{8}{|l|}{ Innovation } \\
\hline $\mathrm{U} \Delta$ Quality * Pioneering & & & & & & .158 & .111 \\
\hline
\end{tabular}




\begin{tabular}{|c|c|c|c|c|c|}
\hline Variables & Hyp. & Std. Error & Std. Error & Estimate & Std. Error \\
\hline & & Fama-French Variables & Pauwels et al. Variables & Focal Model & \\
\hline \multicolumn{6}{|l|}{ Category Characteristics } \\
\hline $\mathrm{U} \Delta$ Size & & & & .018 & .212 \\
\hline $\mathrm{U} \Delta$ Size * U $\Delta$ Innovation & & & & $.220 *$ & .052 \\
\hline $\mathrm{U} \Delta$ Growth Rate & & & & .365 & 1.181 \\
\hline $\mathrm{U} \Delta$ Growth Rate * U $\Delta$ Innovation & & & & $.618^{*}$ & .234 \\
\hline $\mathrm{U} \Delta$ Share of Category & & & & -.141 & .128 \\
\hline $\mathrm{U} \Delta$ Share $*$ U $\Delta$ Innovation & & & & .079 & .962 \\
\hline $\mathrm{U} \Delta$ Concentration & & & & -.432 & .420 \\
\hline $\mathrm{U} \Delta$ Concentration $* \mathrm{U} \Delta$ Innovation & & & & .129 & .121 \\
\hline $\begin{array}{l}\text { Durbin-Watson Statistic for Serial } \\
\text { Correlation }\end{array}$ & & 2.072 & 2.080 & 2.103 & \\
\hline Adjusted R-squared & & .154 & .334 & .472 & \\
\hline
\end{tabular}

Note: Model also includes the seasonal dummies and the brand- and firm-specific fixed coefficients, which are not displayed in the interest of space; *-Significant at $\mathrm{p}=.01 ;{ }^{* *}$ - Significant at $\mathrm{p}=.05$ and using two-sided tests of significance. As for the number of observations, there are 54 brands x 299 weeks in the cross-sectional time-series panel. The DW test statistic is obtained using EViews 6 (see Johnston and DiNardo 1997, Chapter 6.6.1). 
TABLE 8

Impact of Firm Actions on Stock Returns

Impact of...

Effect on Stock Returns

$\begin{array}{cc}\begin{array}{c}\text { Pauwels et al. } \\ \text { variables } \\ (\text { Table 7, col. 5) }\end{array} & \text { Focal model } \\ & \text { (Table 7, col.7) }\end{array}$

\section{New-Product Introductions}

Level 1

$.47 \%$

$.55 \%$

Level 2

$.23 \%$

$.43 \%$

Level 3

$.20 \%$

$.38 \%$

Level 4

$.16 \%$

$.34 \%$

Level 5

$.65 \%$

$.98 \%$

Pioneering innovations

$4.28 \%$

Advertising support for new-product introductions

$.10 \%$

Advertising support for pioneering innovations

$.91 \%$

Promotional support for new-product introductions

$-.20 \%$

Improvement in customer liking for new-product

n.s.

introductions

Improvement in perceived quality for new-product

$2.10 \%$ introductions

\section{Note:}

$>$ The numerical simulations examine the impact of a) introducing a new product, b) introducing a pioneering innovation, c) increasing advertising support for a level-1 innovation by $\$ 1$ million, d) increasing promotional support for a level-1 innovation by $\$ 1000$, e) increasing the customer liking for a level-1 innovation by 100 points, f) increasing the perceived quality for a level-1 innovation (i.e., reducing the number of defects) by 100 points; n.s. denotes that the estimate is not significant.

$>$ The simulation for the impact of a pioneering innovation is based on the assumption that when a pioneering innovation is introduced, the level of innovation increases from level 0 to level 5. 


\section{REFERENCES}

Aaker, David A. and Robert Jacobson (1990), "The Risk of Marketing: The Roles of Systematic, Uncontrollable, and Controllable Unsystematic, and Downside Risk,” in R. A. Bettis and H. Thomas (eds.) Risk, Strategy, and Management, Greenwich, CT: JAI Press, 137-160.

Aaker, David and Robert Jacobson (1994), “The Financial Information Content of Perceived Quality,” Journal of Marketing Research, 31, 191-201.

Aaker, David and Robert Jacobson (2001), "The Value Relevance of Brand Attitude in HighTechnology Categories,” Journal of Marketing Research, 38, 485-493.

Agarwal, Rajshree and Barry L. Bayus (2002), "The Market Evolution and Sales Takeoff of Product Innovations,” Management Science, 48(8), 1024-1041.

Ball, Ray and Phillip Brown (1968), “An Empirical Evaluation of Accounting Income Numbers,” Journal of Accounting Research, 6(Autumn), 159-178.

Barth, Mary E., Michael B. Clement, George Foster, and Ron Kasznik (1998), "Brand Values and Capital Market Valuation,” Review of Accounting Studies (3)1-2, 41-68.

Bayus, Barry, Gary Erickson, and Robert Jacobson (2003), "The Financial Rewards of New-Product Introductions in the Personal Computer Industry,” Management Science, 49(2), 197-210.

Bly, Robert W. (1993), Advertising Managers' Handbook. Prentice Hall, Englewood Cliffs, NJ.

Booz, Allen, Hamilton (1982), New Product Management for the 1980's, New York: Booz Allen Hamilton.

Boulding, William, Lee Eunkyu, and Richard Staelin (1994), "Mastering the mix: Do advertising, promotion, and sales force activities lead to differentiation?” Journal of Marketing Research, 31(2), 159-172.

Boulding, William, Ruskin Morgan, and Richard Staelin (1997), "Pulling the Plug to Stop the New Product Drain,” Journal of Marketing Research, 34(February), 164-176.

Bowman, Douglas and Hubert Gatignon (1996), "Order of Entry as a Moderator of the Effect of the Marketing-Mix on Market Share,” Marketing Science, 15(3), 222-242.

Capon, Noel, John U. Farley, and Scott Hoenig (1996), Toward Integrative Explanation of Corporate Financial Performance, Norwell, MA: Kluwer Academic Publishers.

Chandy, Rajesh and Gerard J. Tellis (2000), “The Incumbents' Curse? Incumbency, Size and Radical Product Innovation,” Journal of Marketing, 64(3), 1-17.

Chaney, Paul, Timothy Devinney, and Russ Winer (1991), “The Impact of New-Product Introductions on the Market Value of Firms,” Journal of Business, 64(4), 573-610.

Cheng, Agnes C.S. and Charles J.P. Chen (1997), "Firm Valuation of Advertising Expense: An Investigation of Scaler Effects,” Managerial Finance, 23(10), 41-61. 
Cooper, Robert (2005), Product Leadership: Pathways to Profitable Innovation, New York: Basic Books.

Cooper, Robert (1999), “How New Product Strategies Impact on Performance,” Journal of Product Innovation Management, (1), 5-18.

Cooper, Robert and Elko J. Kleinschmidt (1993), "The Impact of Product Innovativeness on Performance,” Journal of Product Innovation Management, (10), 90-111.

Cubbin, John and Simon Domberger (1988), “Advertising and Post-entry Oligopoly Behavior," Journal of Industrial Economics, 37 (December), 123-140.

Davidson, Russell and James G. MacKinnon (1993), Estimation and Inference in Econometrics, New York: Oxford University Press.

Dekimpe, Marnik G. and Dominique M. Hanssens (1999), "Sustained Spending and Persistent Response: A New Look at Long-Term Marketing Profitability," Journal of Marketing Research, 36(November), 397-412.

Dekimpe, Marnik G. and Dominique M. Hanssens (2000), “Time-series Models in Marketing: Past, Present and Future,” International Journal of Research in Marketing, 17(2-3), 183-193.

Dowling, Grahame and Richard Staelin (1994), “A Model of Perceived Risk and Intended RiskHandling Activity,” Journal of Consumer Research, (21), 119-134.

Dresdner Kleinwort Benson Research (2000), The Business Case for the Double Decker. May 8, 34.

Drucker, Peter (1973), Management: Tasks, Responsibilities and Practices, New York: Harper \& Row.

The Economist (2004), A Survey of the Car Industry, September 4-10.

Ehrenberg Andrew (1988), Repeat-buying: Facts, Theory and Applications, 2nd ed., Edward Arnold, London, Oxford University Press, New York.

Eldridge, Earl (2004), “Cadillac Escalade Courts Hip Trendsetters,” USA Today, Monday March 22.

Engle, Robert F. (1982), “Autoregressive Conditional Heteroscedasticity with Estimates of Variance of United Kingdom Inflation,” Econometrica (50) 987-1008.

EViews (2007), EViews 6 User's Guide, Quantitative Micro Software, Irvine, California.

Fama, Eugene and Kenneth French (1992), “The Cross-section of Expected Stock Returns,” Journal of Finance, 47(2), 427-465.

Fama, Eugene and Kenneth French (1993), "Common Risk Factors in the Returns on Stocks and Bonds,” Journal of Financial Economics, 33, 3-56. 
Fischer, Marc, Hyun Shin, and Dominique M. Hanssens (2007), "Marketing Spending and the Volatility of Revenues and Cash Flows," working paper, UCLA Anderson School of Management, October.

Fisher, Marshall, Kamalini Ramdas, and Karl Ulrich (1999), "Component Sharing in the Management of Product Variety: A Study of Automotive Braking Systems,” Management Science, 45(3), 297-315.

Franses, Philip Hans (2002), Concise Introduction to Econometrics: An Intuitive Guide, Cambridge University Press.

Frey, John B. (1988), “Commentary on 'Marketing Mix Reactions to Entry’,” Marketing Science, 7, 386-387.

Gatignon, Hubert and Thomas S. Robertson (1985), “A Propositional Inventory for New Diffusion Research,” Journal of Consumer Research, 11(March), 849-867.

Geyskens, Inge, Katrijn Gielens, and Marnik G. Dekimpe (2002), “The Market Valuation of Internet Channel Additions,” Journal of Marketing, 66(2), 102-119.

Ghemawat, Pankaj (1991),“Market Incumbency and Technological Inertia,” Marketing Science, (10), 161-171.

Gielens, Katrijn and Marnik G. Dekimpe (2001), "Do International Entry Decisions of Retail Chains Matter in the Long Run?” International Journal of Research in Marketing, 18(3), 235-259.

Gielens, Katrijn and Jan-Benedict E.M. Steenkamp (2003), “Consumer and Market Drivers of The Trial Probability of New Consumer Packaged Goods” Journal of Consumer Research, 30 (December), 368-383.

Gielens, Katrijn and Jan-Benedict E.M. Steenkamp (2007), "Drivers of Consumer Acceptance of New Packaged Goods: An Investigation across Products and Countries,” International Journal of Research in Marketing, 24 (June), 97-112.

Griffin, Abbie and John R. Hauser (1993), “The Voice of the Customer,” Marketing Science, 12(1), 128.

Hanssens, Dominique M. and Ming Ouyang (2002), "Hysteresis in Market Response: When is marketing spending an investment?,” Review of Marketing Science, 419

Hanssens, Dominique M., Leonard J. Parsons, and Randall L. Schultz (2001), Market Response Models: Econometric and Time Series Analysis, 2nd edition, Kluwer Academic Publishers.

Hauser John, Gerard J. Tellis, and Abbie Griffin (2006), "Research on Innovation and New Products: A review and Agenda for Marketing Science,” Marketing Science 25 (6), 686-717.

Henard, David and David M. Szymanski (2001), "Why Some New Products Are More Successful Than Others,” Journal of Marketing Research, 38(August), 363-375.

Holak, Susan and Donald R. Lehmann (1990), "Purchase Intentions and Dimensions of Innovation: An Exploratory Model,” Journal of Product Innovation Management, (7), 59-73. 
Hsiao, Cheng (2003), Analysis of Panel Data, 2nd ed., Cambridge University Press.

Jacobson, Robert and David Aaker (1993), "Myopic Management Behavior with Efficient, But Imperfect, Financial Markets, ” Journal of Accounting Economics, (16), 383-405.

J.D. Power and Associates (2002), GM Expresses New Confidence, Powergram, April 24.

Johnston, Jack and John Dinardo (1997), Econometric Methods, McGraw-Hill/Irwin, New York, NY.

Joshi, Amit M. and Dominique M. Hanssens (2007), "Advertising Spending and Market Capitalization,” working paper, UCLA Anderson School of Management, April.

Joshi, Amit M. and Dominique M. Hanssens (2008), "Movie Advertising and the Stock Market Valuation of Studios: A Case of Great Expectations?,” Marketing Science, forthcoming..

Kamakura, Wagner A. and Gary. J. Russell (1994), "Understanding Brand Competition Using Micro and Macro Scanner Data,” Journal of Marketing Research, 31(May), 289-303.

Kashani, Kamran (2003), “The Path to Growth: The Power of Brand Innovation,” Innovation Europe 56- 58.

Kashani, Kamran, Joyce Miller, and Tony Clayton, (2000), A Virtuous Cycle: Innovation, Consumer Value, and Communication: Key Findings for Policy-Makers and Chief Executives, Lausanne: International Institute for Management Development.

Kleinschmidt, E.J. and Robert G. Cooper (1991), “The Impact of Product Innovativeness on Performance,” Journal of Product Innovation Management, 8(December), 240-251.

Kormendi, Roger and Robert Lipe (1987), “Earnings Innovations, Earnings Persistence and Stock Return,”Journal of Business, 60(3), 207-238.

Kothari, S.P. (2001), “Capital Markets Research in Accounting," Journal of Accounting and Economics, 31, 105-231.

Lane, Vicki and Robert Jacobson (1995), "Stock Market Reactions to Brand Extension Announcements: The Effects of Brand Attitude and Familiarity," Journal of Marketing, 59(January), 63-77.

Lee, Hau, V. Padmanabhan and Seungjin Whang (1997), "Information Distortion in a Supply Chain: The Bullwhip Effect," Management Science, 43(4), April, 546-558.

Lehmann, Donald (2004), “Metrics for Making Marketing Matter,” Journal of Marketing, (68), 73-75.

Lodish, Leonard M., Magid M. Abraham, Jeanne Livelsberger, Beth Lubetkin, Bruce Richardson and Mary Ellen Stevens (1995), “A Summary of Fifty-Five In-Market Experimental Estimates of the Long-Term Effect of TV Advertising,” Marketing Science, 14(3), 133-140. 
Madden, T.J., Frank Fehle, and Susan Fournier (2006), "Brands Matter: An Empirical Demonstration of the Creation of Shareholder Value through Branding," Journal of the Academy of Marketing Science, 34 (2), 224-235.

Malkiel, Burton (1973), “A Random Walk Down Wall Street,” New York: WW Norton \& Co.

Marketing Science Institute (2004), 2004-2006 Research Priorities: A Guide to MSI Research Programs and Procedures, Cambridge, MA: Marketing Science Institute.

Markovitch, Dmitri, Joel H. Steckel, and Bernard Yeung (2005), "Using Capital Markets as Market Intelligence: Evidence from the Pharmaceutical Industry," Management Science, 51 (10), $1467-1480$.

Mizik, Natalie and Robert Jacobson (2003), "Trading Off Between Value Creation and Value Appropriation: The Financial Implications of Shifts in Strategic Emphasis,” Journal of Marketing, 67(1), January, 63-76.

Mizik, Natalie and Robert Jacobson (2004), “Stock Return Response Modeling,” in Christine Moorman and Donald R. Lehmann (eds.) Assessing Marketing Strategy Performance: How Do We Get There?, Cambridge, MA: Marketing Science Institute.

Montoya-Weiss, M.M. and Roger J. Calantone (1994), "Determinants of new product performance: A review and meta-analysis,” Journal of Product Innovation Management, (11), 397-417.

Moorman, Christine and Anne Miner (1997), "The Impact of Organizational Memory on New Product Performance and Creativity,” Journal of Marketing Research, 34(February) 91-106.

Nijs, Vincent R., Marnik G. Dekimpe, Jan-Benedict E. M. Steenkamp and Dominique M. Hanssens (2001), “The Category-Demand Effects of Price Promotions," Marketing Science, 20, 1, 1-22.

Pauwels, Koen, Jorge Silva-Risso, Shuba Srinivasan, and Dominique M. Hanssens (2004), "New Products, Sales Promotions and Firm Value, With Application to the Automobile Industry," Journal of Marketing, 68(October), 142-156.

Phillips Lynn, W., Dae R. Chang, and Robert D. Buzzell (1983), "Product Quality, Cost Position and Business Performance: A Test of Some Key Hypotheses,” Journal of Marketing 47, 26-43.

Robertson, Thomas S. (1993), “How to Reduce Market Penetration Cycle Times,” Sloan Management Review, 35(Fall), 87-96.

Rust, Roland T., Tim Ambler, Gregory S. Carpenter, V. Kumar, and Rajendra K. Srivastava (2004), "Measuring Marketing Productivity: Current Knowledge and Future Directions," Journal of Marketing, (68), 76-89.

Scherer, Frederic M. (1980), Industrial Market Structure and Economic Performance, Chicago: Rand McNally.

Sherman, Roger and George Hoffer (1971), “Does Automobile Style Change Pay Off?” Applied Economics, (3), 153-165. 
Sivadas, Eugene and Robert F. Dwyer (2000), “A Comparison of Organizational Factors Influencing New Product Success in Internal and Alliance based Processes,” Journal of Marketing, 64 (1), 31-49.

Sorescu, Alina, Venkatesh Shankar, and Tarun Kushwaha (2007), "New Product Preannouncements and Shareholder Value: Don’t Make Promises You Can’t Keep,” Journal of Marketing Research, 44(3), 468-489.

Srinivasan, Shuba, Koen Pauwels, Dominique M. Hanssens, and Marnik Dekimpe (2004), "Do Promotions Benefit Retailers, Manufacturers, or Both?” Management Science, 50(5), May, 617-629.

Srivastava, Rajendra, Tasadduq A. Shervani, and Liam Fahey (1998), "Market-Based Assets and Shareholder Value: A Framework for Analysis,” Journal of Marketing, (January), 1-18.

Srivastava, Rajendra, Tasadduq A. Shervani, and Liam Fahey (1999), "Marketing, Business Processes, and Shareholder Value: An Organizationally Embedded View of Marketing Activities and The Discipline of Marketing,” Journal of Marketing, 63(Special Issue), 168-179.

Tellis, Gerard J. and Joseph Johnson (2007), “The Value of Quality,” Marketing Science, 26 (6), 758773.

TNS Media Intelligence (2005), U.S. Advertising Market Shows Strong Growth in 2004, $<$ http://www.tns-mi.com/news/03082005.htm>.

van Dijk, Dick, Philip Hans Franses, and Andre Lucas (1999), "Testing for ARCH in the presence of additive outliers,” Journal of Applied Econometrics, (14), 539-562.

Wall Street Journal (1997), “Boeing’s 747 Shifts Rivalry with Airbus,” January 22, A3.

Wensley, Robin (1981), “Strategic Marketing: Betas, Boxes, or Basics,” Journal of Marketing, (45) 173-182.

White, Joseph B. (2001), "Ford and GM Work to Restore Prestige of Lincoln and Cadillac,” The Wall Street Journal, Eyes on the Road, December 3. 


\section{Endnotes}

1 A good example of these inter-temporal effects in the car industry is a "lease pull ahead" program. Analysts at car manufacturers keep track of the patterns of lease expirations. When they spot a month in the future with an unusually large volume of lease returns, they offer some of those lessees the option to return the car ahead of time, coinciding with a period of lower expected lease returns, or offer a promotional extension of the lease term. Furthermore, it is a common practice to target lease programs to terms coinciding with an expected "valley" in lease returns. By seeking a stable flow of lease returns, manufacturers aim to generate a stable flow of new leases.

2 Specifically, we are interested in the extent to which a new automobile model introduced is different from current offerings of the firm and those in the market. We do not consider specific innovations in processes or components.

3 Within the context of the automobile industry, there are six categories based on the accepted industry classifications: SUVs, minivans, mid-size sedans, compact cars, compact pick-ups and full-size pick-ups.

$4 \quad$ <http://mba.tuck.dartmouth.edu/pages/faculty/ken.french/data_library.html>

5 Ideally, one would want to run the regression $R E T^{B R A N D}=b X+\mu$ where $R E T^{B R A N D}$ is the return associated exclusively with the particular brand information $X$. However, given the corporate nature of stock returns, the regression we estimate is $R E T=\beta X+\varepsilon$ where $R E T$ is the total corporate stock return, which is composed of $R E T^{B R A N D}$ and $R E T^{N O T-B R A N D}$, i.e. the stock return that is not associated with the brand. Because $R E T=\left(R E T^{B R A N D}+R E T^{N O T-B R A N D}\right)$, it can be shown that the least-squares estimate of $E[\beta]=E\left[\left(X^{\prime} X\right)^{-1} X^{\prime}\left(R E T^{B R A N D}+R E T^{N O T-B R A N D}\right)\right]=b$ (Lane and Jacobson 1995; Geyskens, Gielens and Dekimpe 2002), leading to an unbiased estimate under the reasonable assumption that $R E T^{N O T-B R A N D}$ and $X$ are uncorrelated. As a further test of this assumption, we estimate an expanded model including cannibalization effects of other brands owned by the same firm and find that our substantive results are robust to this issue (see footnote 12 below for details).

6 With the exception of price promotions, all the other variables come from national sources. In the auto industry, typically, promotions are planned and executed at the national level, and they are advertised nationally through TV networks. As such, the price promotions data from California are quite representative of the price promotions of other U.S. regions.

7 Moreover, this dataset is at the detailed 'vehicle' level, defined as every combination of model year, make and model (e.g., 1999 Honda Accord, 2000 Toyota Camry), body type (e.g., convertible, coupe, hatchback), doors (e.g., 2-door, 4door, 4-door extended cabin), trim level (e.g., for Honda Accord, DX, EX, LX, etc.), drive train type (e.g., 2WD, 4WD), transmission type (i.e., automatic, manual), cylinders (e.g., 4 cylinder, V6), and displacement (e.g., 3.0 or 3.3 liters).

8 For reasons of parsimony, we restrict our attention to those brands that together account for at least $80 \%$ of the share of the category under consideration.

9 The customer liking and perceived quality variables are aggregated to the brand level as the market-share weighted average of the respective ratings of the models for brand $j$. This allows us to incorporate the effects of changes in the vehicle model-mix on firm valuation. For instance, if market conditions cause a drop in sales of full-size SUVs relative to mid-size SUVs, the product lines of General Motors and Ford becomes less attractive relative to those of Toyota and Nissan.

10 Unit-root tests reveal evolution in income and revenue but stationarity in stock returns, the marketing variables and the category-specific variables. A cointegration test for the existence of a long-run equilibrium among these evolving variables produced a negative result.

11 One could also construct an argument in favor of a random coefficients model, using tests to detect such departure from the constant-parameter assumption. As such, we tested for this using the variation of the Lagragian multiplier test proposed by Hsiao (2003, p. 147-149). A $\chi 2$-test (using a significance level of $\mathrm{p}<0.05$ ) did not reveal departure from the assumption of fixed coefficients.

12 We also examined the robustness of our results with an expanded model that incorporates the effects of other brands owned by the same firm. This model thus includes two types of competitive variables: first, we control for competition from brands of the same firm within the same category to account for cannibalization. Second, we consider competition from brands of competing firms in the same category to account for cross effects. No substantial differences in the results are observed between the expanded model and the focal model, indicating that our statistical inference is robust to this issue. 